\title{
Phytochemicals and Their Antimicrobial Activity: An Update on Their Mode of Action
}

\author{
Sravanthi Pammi S. S. 1,*, Archana Giri \\ ${ }^{1}$ Department of Botany, SVRK (M) GDC, Nidadavole, W.G.DT., A.P, India. \\ ${ }^{2}$ Centre for Biotechnology, Institute of Science and Technology, Jawaharlal Nehru Technological University Hyderabad, Kukatpally, \\ Hyderabad 500 085, India.
}

How to cite this paper: Sravanthi Pammi S. S., Archana Giri. (2021) Phytochemicals and Their Antimicrobial Activity: An Update on Their Mode of Action. International Journal of Clinical and Experimental Medicine Research, 5(1), 41-69.

DOI: 10.26855/ijcemr.2021.01.008

Received: December 11, 2020

Accepted: January 8, 2021

Published: January 19, 2021

*Corresponding author: Sravanthi Pammi S. S., Department of Botany, SVRK (M) GDC, Nidadavole, W.G.DT., A.P, India.

Email: pammisravanthi@gmail.com

\begin{abstract}
Introduction: Plants have been considered as potential alternative for antimicrobial antibiotics owing to vast reserve of secondary metabolites. Last few decades have experienced an upsurge in demand and delivery of herbal products for health benefits as plant derived bioactive compounds have capability to interact with a wide variety of targets. The main focus of this review was to congregate vital information related to imperative bioactive components of medicinal plants having therapeutic potential with particular reference to antimicrobial activity against pathogenic bacteria. Our study intended to comprehend the mode of action of these phytopharmaceuticals for their scientific validation and drug development. Methods: A narrative review of papers reporting antimicrobial activity of medicinal plants against pathogenic bacteria, identification of the prospective bioactive compounds with antimicrobial potential and understanding their mechanism of action has been envisaged. Results: This review includes anthology of recent published information on phytoconstituents of various medicinal plants belonging to different families around the globe, tested and validated against various pathogenic bacteria. This study unveils the treasure of antimicrobial potential of plant species, which is also an appraisal of information related to mechanism of action of these phytochemicals required for their antimicrobial activity. Conclusions: There is resurgence in use of herbal medicines and identification of pharmacologically active compounds with their scientific validation. It will play a pivotal role in perpetuating and promoting wider usages of drugs based on plant extracts. A missing link for establishment of phytocompounds as an alternative drug requires understanding their mode of action and exploitation.
\end{abstract}

\section{Keywords}

Medicinal plants, secondary metabolites, phytochemicals, antimicrobial activity, mode of action

\section{Introduction}

Medicinal plants have been rich source of therapeutically important compounds, used traditionally worldwide as remedies for the treatment of a number of diseases. Plants synthesize myriad biologically active phytochemicals which allow them to exist in their environment including defense against biotic stress [1]. Since antiquity plants have been used by man to treat common infectious diseases. In the past few decades the search for new antimicro- 
bials has engaged many research groups in this field [2]. Approximately 100,000 plant species have a record of medicinal use [3] and they pose to be prospective reservoirs for new drug discovery [4]. Newman [5] reported that out of 109 new antibacterial drugs which got approval between 1981 and 2006, 69\% are of natural product origin. Therapeutic use of formulations having physiologically active constituents has a record in folk medicines for treatment of various infectious diseases and possess a unique combination of secondary metabolites having potent biological activities and can be used as an alternative for the treatment of diseases especially in developing countries where people don't have access to health care [6]. Traditional system of medicine is practiced in many developing countries [7]. Richness in bio-diversity of Indian flora was well recognized all over the world which helped in documentation of natural resources in the form of books, treaties and research papers etc. It is very interesting to know that even in $21^{\text {st }}$ century, $70 \%$ of population in villages use herbal therapy for health problems and Ayurvedic system is still proving itself to the needy people. Advanced tools and analytical techniques help in extraction of these active principles for use in modern medicine [8]. One major asset of medicinal plant-based drug discovery is the existence of ethnopharmacological information providing hints for compounds therapeutically effective in humans [9]. Phytochemicals which are mostly secondary metabolites are exceptionally complex with low molecular weight and difficult to synthesize. Medicinal plants are named as "Ultimate factories" as they are crucial for attaining health.World Bank reported that there is an annual increase in growth rate of herbal medicine from 5\% to $15 \%$ [10]. WHO recognized the importance of traditional medicine integrated with other sciences. It has also been focusing on evidence-based strategy of traditional medicines as global health care needs to be strengthened.

A substantial proportion of deaths worldwide are owing to infectious diseases. Treatment of many infectious diseases is threatened by the growing resistance of pathogens to the drugs. Excessive use of antibiotics is responsible for emergence of antibiotic resistant bacteria, which renders current antibiotics insufficient to control bacterial infection. Epidemiology of resistance is complex and moreover the problem is aggravated by lack of success in developing novel antibiotics. There is a renewed interest in the study of medicinal plants as potential sources of new antibacterial agents; it is an important line of research owing to antibiotic resistance acquired by microorganisms [11]. There are several reports mentioning the role of secondary metabolites as potential antibacterial agents [12].

Plant extracts provide therapeutic modalities with broad spectrum antimicrobial activities against various pathogens [13]. Last few decades have experienced an upsurge in demand and delivery of these herbal products for health benefits. Currently herbal therapy has taken a front seat and researchers are identifying pharmacologically active compounds, their biological activities and scientific validation. It will play a pivotal role in perpetuating and promoting wider usages of drugs based on plant extracts. Plant extracts possess multidimensional health benefits, phytoconstituents are also beneficial in maintenance and boosting of general health conditions. There are variations in active principles; however, it forms a bunch of safer, cost effective and easily available medicines [13, 14]. A missing link of use of phytochemicals as antimicrobials is their mode of action. There are large number of publications which report antimicrobial activity of isolated pure compounds against bacterial pathogens. However, only few report their mode of action. There is a resurgence of use of herbal medicine. Natural products are considered as privileged group of compounds which interact with wide variety of targets. Plant extracts as complete mixture of secondary metabolites also exude synergistic effect with conventional antibiotics [15].

Conventional therapy using antibiotics is found to be untreatable to many of existing infectious diseases due to the presence of multidrug-resistant bacteria. Therefore, efforts are being made to target bacterial resistance mechanisms by developing new drugs obtained from natural products, especially plants. Plants have structurally diverse and complex compounds with unique properties showing outstanding performance. Researchers are focusing on innovative strategies to eradicate multidrug-resistant bacteria by using these phytochemicals [16]. Even though plant-derived phytochemicals are many times weaker compared to antibiotics produced by bacteria [17], plants can fight against these infections effectively. There should be a serious consideration of unusual infections causing adverse side effects for solving actual health problems of society [18]. A thorough review is mandatory to investigate and validate the plant extracts with better understanding of their biological and pharmacological properties.

This review is an attempt in this direction to compile the antimicrobial activity of plant extracts and get an insight into their mode of action. Authors have made an attempt to compile the information about various plants with antimicrobial applications and role of their phytoconstituents to combat microbial infection to understand their mode of action as an alternative to conventional antibiotics it also discusses the potential of phytochemicals for drug development.

\section{Phytopharmaceuticals; Pharmacologically significant compounds:}

Crude extracts serve as wonderful drugs to humans for treatment of various diseases thus explaining the potential 
of medicinal plants and their extracts for development of novel drugs [19]. Lavatera thuringiaca L. extracts rich in bioactive compound were found to possess wide range of biological activities such as antimicrobial, antioxidant, cytotoxic, antiviral, antiallergic, anti-inflammatory and many more [20]. Three halophyte species viz. Arthrocnemum macrostachyum, Halimione portulacoides and Salicornia europaea were considered for novel phytopharmaceuticals development as they were found to be potential sources of biologically-active compounds [21]. Euphorbia denticulata was identified as a promising source of phytochemicals which help in the development of novel functional formulations [22]. Plantago lanceolata plant was scientifically justified for its use against various diseases affecting humans as its leaves are identified to be good source of important phytochemicals [23].

Andrographis paniculata extract was analyzed for its phytochemical profile; compounds identified include phenols, esters and aromatic carboxylic acids, which might be responsible for antimicrobial activity against Gram positive and Gram negative bacteria [24]. Gymnema sylvestre was analyzed for its phytochemical and antimicrobial activity using various solvents and high activity was exhibited by aerial and root parts. The compounds oleic acid, eicosane, vitamin $\mathrm{E}$ and stigmasterol were anticipated to be responsible for its excellent antimicrobial activity [25].

All the strategies using phytochemicals can be used for the advancement of novel compounds with enhanced therapeutic activity. Natural products may be difficult to supply and working may be slow, but chemical diversity of natural products gives successful drugs against multidrug resistant pathogens [26]. Medicinal herbs can either influence the immune status of the host or the pathogenicity of the pathogen and can even modulate the disease production site. Some active ingredients in thyme such as Thymol and Carvacrol exhibit their antimicrobial action by penetration into Gram negative bacteria resulting in lysis of bacterial cell [27, 28]. Phytochemicals such as Vitamin $\mathrm{C}$ and carotenoids increase the antigenic surveillance of the immune system thereby reducing the risk of infections [29- 31]. The roots of Ashwagandha were found to have steroidal alkaloids and lactones which enhance the engulfing power of macrophages and other immune cells which in turn helps in antimicrobial action against Salmonella [32, 33]. Canberry was found to interfere with bacterial adherence to bladder lining and helps to prevent infection. Many herbal plants inhibit cyclooxygenase-2, 5-lipoxygenase and glutathione S-transferase which further inhibit prostaglandin biosynthesis and exhibit anti-inflammatory action. Some herbs decrease the production of inflammatory agents such as histamine, serotonin and enhance the activity of cortisol which help in removal of bacterial toxins out of body [34, 35].

Some herbs were found to proliferate CD4+ T-helper and B-cells, and some block NF-eB pathway in infected cells which causes bacterial death by damaging cell membrane causing loss of electrolytes and intracellular contents [36-43].

\section{Antibiotic resistance:}

Bacteria have the capability to develop simultaneous resistance to numerous classes of antibiotics [44]. There is also a risk concern to human and ecological health by the detection of genetic resistance determinants in microbial community [45]. Absence of effective natural antimicrobial agents and increase of multiple drug resistant bacteria focused global concern for health care at present [46].

Various mechanisms are displayed by bacteria for defending themselves against different antimicrobial agents. Emergence of resistant phenotypes is contributed by various factors such as [47, 48]:

- Extent of the expression exhibited by resistance determinants.

- The capacity of bacteria to sustain resistance mechanisms.

- Transmission capacity.

- $\quad$ Fitness of bacteria.

- Reversibility potential.

Bacteria which are susceptible may turn into resistant species by usage of antibiotics through many complex mechanisms (Figure 1):

- $\quad$ Reducing antibiotic permeability by preventing its contact to target site.

- Increasing the expression of antibiotic efflux pumps.

- Antibiotic target site alteration.

- $\quad$ Production of antibiotic degrading enzymes.

\section{Mechanisms of anti-microbial action:}

Most of the antimicrobials exert their effect by any of the following mechanism of action (Figure 2): 


\section{Inhibition of Cell Wall Synthesis [49]:}

$>$ Inhibiting peptidoglycan synthesis.

$>$ Disrupting peptidoglycan cross-linkage.

$>$ Disrupting peptidoglycan precursors movement.

$>$ Disrupting synthesis of mycolic acid or arabinoglycans.

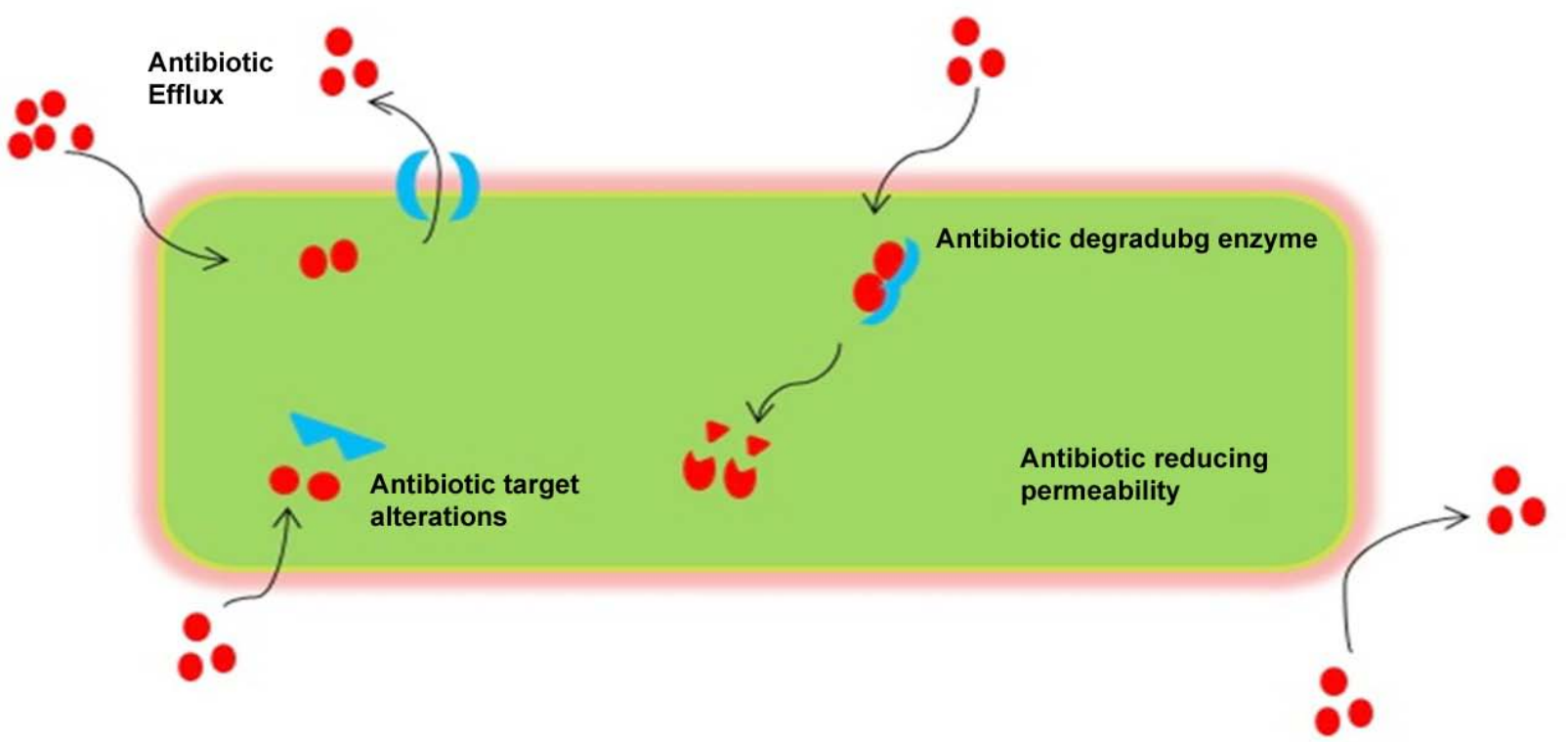

Figure 1. Various resistance mechanisms exhibited by bacteria to antibiotics.

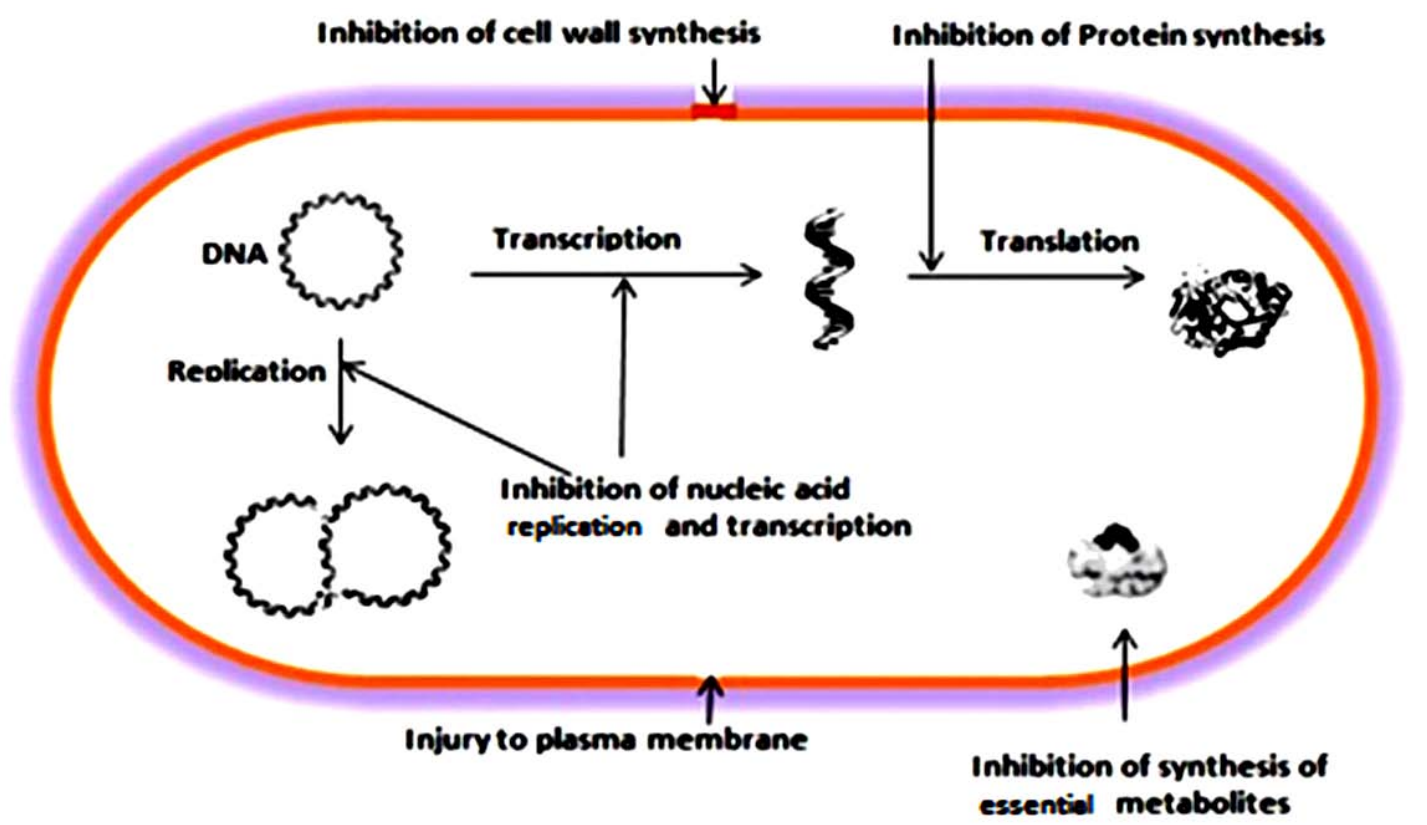

Figure 2. Mechanisms of anti-microbial action of phytochemicals.

\section{Inhibition of protein synthesis}

$>$ Irreversible binding of antibacterial compound to 30S ribosomal binding site.

$>$ Blocking the tRNA from binding to 30S ribosome-mRNA complex.

$>$ Blocking peptide elongation by binding of antibacterial compound to peptidyltransferase site of 50S ribosome.

$>$ Blocking peptide elongation by reversible binding of antibacterial compound to 50 S ribosome. 
$>$ Blocking peptide elongation by binding of antibacterial compound to 50S ribosome, thereby inhibiting peptidyltransferase from interfering with amino acid-acyl-tRNA complex.

\section{Alteration of cell membranes}

$>$ Cationic detergent-like activity.

$>$ Disruption of cytoplasmic membranes.

\section{Inhibition of Nucleic Acid Synthesis:}

$>$ Inhibiting topoisomerases from binding to alpha subunit required for supercoiling of DNA thereby inhibiting DNA synthesis.

$>$ The antibacterial compound generated as cytotoxic byproduct during metabolism causes disruption to DNA.

$>$ Inhibition of RNA synthesis by binding of antibacterial compound to DNA-dependent RNA polymerase enzyme.

$>$ Inhibition of RNA transcription.

\section{Antimetabolite action:}

$>$ Preventing the synthesis of folic acid by competing with p-aminobenzoic acid (PABA).

$>$ Preventing synthesis of folic acid by inhibiting dihydrofolate reductase.

$>$ Sulfamethoxazole synergism.

\section{Phytochemicals as antimicrobial agents:}

Secondary metabolites of plants are rich source of antimicrobial, antioxidant and anticancer compounds [50-52]. 20th century can be stated for commencement of post-antibiotic era against clinical Multidrug-Resistant Bacteria. The problem of high resistance of pathogenic bacteria is interconnected with many factors. But the major cause of it is indiscriminate use of antibiotics in aquaculture, veterinary medicine and human medicine [53]. Medical treatment using plant extracts is gaining fame in recent days as synergistic reactions of natural plant extracts operate on a range of diseases rather than on a single disorder. This is a global concern at present which challenges us in overcoming resistant antimicrobials by doing research in antimicrobial therapy. Plant extracts are probable sources against bacterial pathogens as they have many antimicrobial compounds. Crude plant extracts are more potent compared to isolated pure compounds for anti-microbial screening. Plant extracts of known anti-microbial properties are validated for knowing their impact in treatment of diseases. This technique of inhibiting pathogens is used for going forward in research of phytomedicine providing exciting results. Release of biologically active principles was well understood in solvents such as ethanol, methanol, n-hexane, etc. Plant extracts were proven to be more dynamic against Gram positive bacteria than Gram negative bacteria [54] and hence Gram negative bacteria are more resistant to plant extracts than Gram positive bacteria. This is due to the peptidoglycan layer of Gram positive bacteria which serves as ineffective permeability barrier to lipophilic solutes, whereas the cell wall of Gram negative bacteria is surrounded by an additional lipopolysaccharide layer which serves as an effective barrier which blocks the penetration of lipophilic solutes [55]. Phyllanthus amarus was tested against various bacterial cultures responsible for urinary tract infections using various solvents and methanolic leaf extract of plant proved to have high inhibitory activity. This was owing to the presence of phenols, flavonoids, alkaloids and triterpenes, which was confirmed by phytochemical analysis [56].

Novel resistance mechanisms have been enormously observed to novel antibiotics. Hence innovative strategies are needed to be developed by use of bioactive compounds. During the past decade, pharmaceutical companies have drawn attention towards potential plant-derived substances exhibiting antimicrobial activity. This is a period of rebirth for usage of herbal medicine [57]. Antimicrobial compounds produced by plants may regulate the resistance of plants indirectly [17]. Plants have capacity to produce drug-resistant inhibitors which have direct application against clinical pathogens [58]. Ethno botanical importance of leaf extracts of Phyllanthus wightianus dealing with antimicrobial activities on various human bacterial and fungal pathogens were reported. GC-MS analysis was done for analyzing active bioactive constituents. Major compounds include N-hexadecanoic acid and 9, 12-octadecaenioic acid which relates their presence with antimicrobial activity [59]. Alpinia galanga was evaluated for its antimicrobial activity against numerous pathogens using various solvents. Methanolic extracts exhibited excellent activity towards these pathogens, which may be due to the presence of compounds such as benzyl alcohol, 5-hydroxymethyl furfural, 3-phenyl-2-butanone, methyl cinnamate and 1, 2, benzene dicarboxylic acid that was 
identified through GC-MS analysis [60]. A woody climber Salacia oblonga was evaluated for its antimicrobial activity against various pathogens using various solvents. Ethyl acetate solvent exhibited good activity using aerial and root parts [61]. The fruits of Terminalia chebula were studied for antimicrobial activity using aqueous solvent against Gram positive and Gram negative bacteria [19]. Ethanolic leaf extracts of Vernonia amygdalina, Vernonia aemulans and Lantana camara were tested against food spoilage bacteria such as Staphylococcus aureus, Escherichia coli, Salmonella typhimurium and Bacillus subtilis, for beer preservation in African brewing industry [62]. It was found that these plants exhibited antimicrobial activity thereby improving shelf life due to the presence of secondary metabolites in plants. This helps us to know the importance of medicinal plants in food technology [62]. Chloroform extract of leaves of Phyllanthus fraternus and phytoconstituents present in them were analysed and they were found to contain compounds such as alkaloids, terpenoid, saponin, tannins and steroids. Hence this plant was also justified for use in traditional medicine [63].

\section{Mode of action of plant secondary metabolites:}

- Phytochemicals were found to be a source of Quorum-Sensing inhibitors/ Biofilm inhibitors where intercellular communication for coordinating the expression is blocked preventing pathogenicity of various Gram-positive and Gram-negative bacteria [64-66].

- $\quad$ Phytochemicals also have great chelating property with metal ions thereby preventing bacterial growth and colony formation $[67,68]$.

- Phytochemicals were reported to inhibit the expression of efflux pumps where the microbial tolerance is reduced [69].

- $\quad$ Plants have also been identified as resistance modifiers and a source of antibiotic adjuvants [57] [65].

- $\quad$ Phytochemicals help in regulation of gene expression and signal transduction pathways [70-72].

- $\quad$ Phenolic compounds of plant were found to be responsible for controlling human pathogenic infections by various molecular mechanisms [73].

- Phytochemicals help in modulation of transcription factors [74] and redox signaling mechanisms [72].

Bacterial infections are becoming difficult to treat as pathogens develop biofilm which aids in host establishment, expansion and disease proliferation. The biofilm structure facilitates survival of these bacteria under hostile conditions including antibiotics. There is a need to develop antibacterial agents which can inhibit and also destroy the mature biofilms thereby increasing susceptibility of microbes to antibiotics. Antibiofilm agents may influence biofilm formation by damaging microbial membrane structure by inhibiting peptidoglycan synthesis or modulating quorum sensing. Plant steroids associate themselves with bacterial proteins and inhibit microbial adhesion, enzymes, cell envelop and transport proteins [75-76]. Effective treatments for the disruption of established biofilms may decrease health care costs related to the treatment and potential replacement of infected implanted prosthetic devices [77]. Mozirandi [66] evaluated antimicrobial activity of chondrillasterol isolated from Vernonia adoensisas biofilm inhibitor.

Famuyide [78] evaluated anti adherence activity of Syzygium and Eugenia plant extracts to understand whether they interfere with the initial process of bacterial adhesion, which is an initial strategy for a few bacterial species in their pathogenesis. Targeting bacterial adhesion may be a novel tool for drug discovery and development to deal with selective pressure for resistance [79].

Plant extracts are potential resistance modifying agents (RMAs) performing multiple modes of action to restore the efficacy of antibiotics against resistant bacteria, which include action on modified target sites, inhibiting bacterial enzymes that inactivate antibiotics, membrane permeabilizing agents and inhibitors of efflux pumps [15]. There are very few reports which have given an insight into their prevalence for resistance reversibility. Secondary metabolites of plants exhibit beneficial effects on mankind due to their potential target site similarities for their action against endogenous ligands, signal transduction molecules or neurotransmitters, hormones and metabolites. The general mechanisms exhibited by phytochemicals mainly include microbial growth inhibition, induction of cellular membrane perturbations, interfering with the processes of microbial metabolism, modulation of redox signaling [80].

Essential oils act as $\beta$ - lactamase inhibitors and bacterial efflux pump inhibitors. Plant derived essential oils can be used in combination with antibiotics as treatment modalities against bacterial infections. [12]. reviewed antimicrobial properties of flavonoids, their mode of action and also discussed the scope of possible replacement of conventional antibiotics. They also discussed about the synergy and additive effect between flavonoids and antibiotics. These are named as resistance modifiers or reversal adjuvants. Essential oils such as the terpenoids, carvacrol and 
thymol, occur extensively in nature and contribute plant flavours and aromas.

Phenols combine with nuclear receptors involved in growth and maintainance of adipogenesis. Active phenol molecules penetrate the cytoplasmic membrane by passive or active diffusion enabling the accumulation of products in bacteria and exhibit its action on cytoplasmic membrane [81].

Plant peptides form ion channels in the membrane of bacterial cells and inhibit the binding of microbial proteins to host polysaccharide receptors [82, 83].

Phytochemical screening of aqueous pulp extract of Tamarindus indica [84] and leaves of Zapoteca portoricensis [85] revealed the presence of high concentration of alkaloids which exhibited antimicrobial activity not only against Gram positive bacteria viz. Staphylococcus aureus but also against Gram negative bacteria viz. Escherichia coli, Pseudomonas aeruginosa. Plants belonging to families Fabaceae, Amaryllidaceae, Mimosaceae, Capparaceae, Rubiaceae, Compositae and Rutaceae were rich in alkaloids and were found to exhibit antibacterial activity against various bacteria [86]. Steroidal alkaloids can also interact with target receptors. Some alkaloids viz. tetrandrine, berbamine and cepharanthine have also been reported to interfere with membrane integrity [87]. Several alkaloids show their effect on multiple functions. Mechanism of antibacterial action of alkaloids was found to differ among alkaloid classes. Synthetic quinolone alkaloids were found to have respiratory inhibition effects. Cell division was inhibited by perturbing the Z-ring using Isoquinolines alkaloids such as berberine, sanguinarine, protoberberine, and benzophenanthridine [88].

Most of the flavonoids were found to exhibit antioxidant, anti-inflammatory and antitumor activities. In presence of other phytochemicals, these flavonoids were found to exhibit antibacterial activities [89]. Phenols and flavonoids in different plant parts of Phyllanthus amarus were found to be responsible for its antimicrobial activity [90]. Aqueous leaf extracts of Zapoteca portoricensis were found to exhibit anti-Pseudomonas aeruginosa activity due to the presence of flavonoid [85]. The leaf and root ethanol extracts of Morinda citrifolia were found to exhibit antimicrobial activity against Pseudomonas aeruginosa and Staphylococcus epidermidis due to the presence of high flavonoid content in them [91]. Plants belonging to families Fabaceae, Amaryllidaceae, Rubiaceae, Labiatae and Rutaceae were rich in Flavonoids and were found to be exhibit antibacterial activity against various bacteria [86]. Flavonoids with more $(\mathrm{OH})$ groups had a greater antimicrobial activity. Flavonoids lacking hydroxyl groups on their $\beta$-rings were more active in membrane disruption in microbial targets [15]. Flavonoid glycosides such as quercetin, apigenin, and luteolin damage cell wall by formation of pores [15]. Phenols and flavonoids in different plant parts of Phyllanthus amarus were found to be responsible for its antimicrobial activity [92].

Tannins were found to exhibit antifungal and antibacterial activities [93] [7]. Ethanol extracts of stem bark of Psidium guajava were found to exhibit antibacterial activity against Staphylococcus aureus, Streptococcus faecalis, Bacillus subtilis, Escherichia coli and Salmonella species. This activity was found to be due to the high concentration of tannins in these plant extracts [94]. Methanolic extract of Acacia nilotica was found to exhibit anti-Staphylococcus aureus activity and anti-Pseudomonas aeruginosa activity, which was found to be due to the presence of high concentration of tannins. In presence of other phytochemicals, these tannins were found to exhibit antibacterial activities [89]. Plants belonging to families Myrtaceae, Fabaceae, Mimosaceae, Rubiaceae and Labiatae were rich in tannins and were found to exhibit antibacterial activity against various bacteria [86]. In Combretaceae, flavonoids and ellagitannins were found to exhibit Quorum sensing/biofilm inhibition [95].

Terpenoids the derivatives of terpenes and the ethanol extracts of stem bark of Psidium guajava were found to have high concentrations of terpenoids. In presence of other phytochemicals of this bark, these terpenoids were found to exhibit anti-Streptococcus faecalis activity [94]. Plants belonging to families Myrtaceae, Compositae, Rubiaceae, Rutaceae, Caesalpinaceae, Amaranthaceae and Labiatae were rich in Terpenes and were found to exhibit antibacterial activity against various bacteria [86]. A terpenoid carvacrol is obtained from oregano [96] [97] and a terpene Eugenol is obtained from clove [97-100].

Antimicrobial study was performed using naphthoquinone enantiomers viz. alkannins and shikonins by Papageorgious [101]. They were very effective in showing wound healing properties by exhibiting antimicrobial and antiinflammatory properties against ulcer development. These naphthoquinone enantiomers were found to exhibit broad antimicrobial spectrum and were proved to exhibit anti-Staphylococcus aureus activity and anti-Staphylococcus epidermidis activity [101]. Plants belonging to families Boraginaceae, Plumbaginaceae, Ebanaceae and Droseraceae, rich in quinones were found to exhibit antibacterial activity against various bacteria [86].

The aqueous pulp extract of Tamarindus indica revealed the presence of two specific resins viz. saponins and glycosides, which were highly active to Staphylococcus aureus [84]. In presence of other phytochemicals, these resins were found to exhibit many biological activities [89]. Ethanolic leaf extract of Ocimum gratissimum revealed the presence of several phytochemicals including saponins and were found to exhibit antimicrobial activity against 
Pseudomonas aeruginosa, Proteus species, Staphylococcus aureus and Shigella dysentriae [102]. Plants belonging to families Labiatae and Fabaceae are rich in resins and were found to exhibit antibacterial activity against various bacteria [86]. Saponins exert toxicity on tissues and exhibit antibacterial activity [103]. Lectins are secondary metabolites of plants, found to exhibit anti-microbial action by cell-cell interaction against Gram positive and Gram negative bacteria [104]. Lectins are proteins or glycoproteins that have at least one binding site without catalytic function or immunological characteristics [105]. Hamed [106] reported separation of lectins from five cultivars of Phaseolus and evaluated their antimicrobial activity against Gram-negative bacteria Pseudomonas aeruginosa and Klebsiella pneumoniae, and Gram-positive bacteria Staphylococcus aureus, the mode of action of lectins was potential agglutination of bacterial cells which was confirmed by scanning electron microscope (SEM) [107] [108] [109]. Lectins in Phaseolus vulgaris were found to agglutinate and aggregate bacterial cells together [106]. Berger [110] reported that glycerol ethers and related compounds present in dimethyl ether extract may be responsible for the antimicrobial activity due to respiratory collapse. Compounds having methoxy group exhibit antimicrobial action by causing distortion to cell surface $[111,112]$. Benzophenone is a photoreactive group and is used for the development of antimicrobial coatings as it interacts with phospholipid bilayer of bacterial cell membrane and alters its structure. This causes stress on the cell wall spilling cytoplasmic material and causing cell death [112]. In Aloe vera, fumaric acid which is an organic acid has been reported as antibacterial component [113]. A series of diphenyl methane compounds display antimicrobial action against various microorganisms [114]. In Malaysian Mangifera indicakernel, Phenol, 2, 4-Bis (1, 1-Dimethyl ethyl) was identified and reported to have antibacterial activity [115]. Sulfur-containing phytochemicals in Brassicaceae and Liliaceae were found to down-regulate the expression of quorum-sensing (QS) virulence factors [116]. In Asteraceae, Chondrillasterol was found to exhibit Biofilm inhibition by leakage of nucleic acids and damage of the lipid layer of the membrane by inhibiting peptidoglycan synthesis, and/or modulating quorum sensing [66]. Secondary metabolites of plants and their modes of action were shown in Table 1.

Various phytochemicals displaying antimicrobial activity is represented in Figure 3. Antimicrobial activities of bioactive compounds of medicinal plants against bacteria were reported in Table 2.

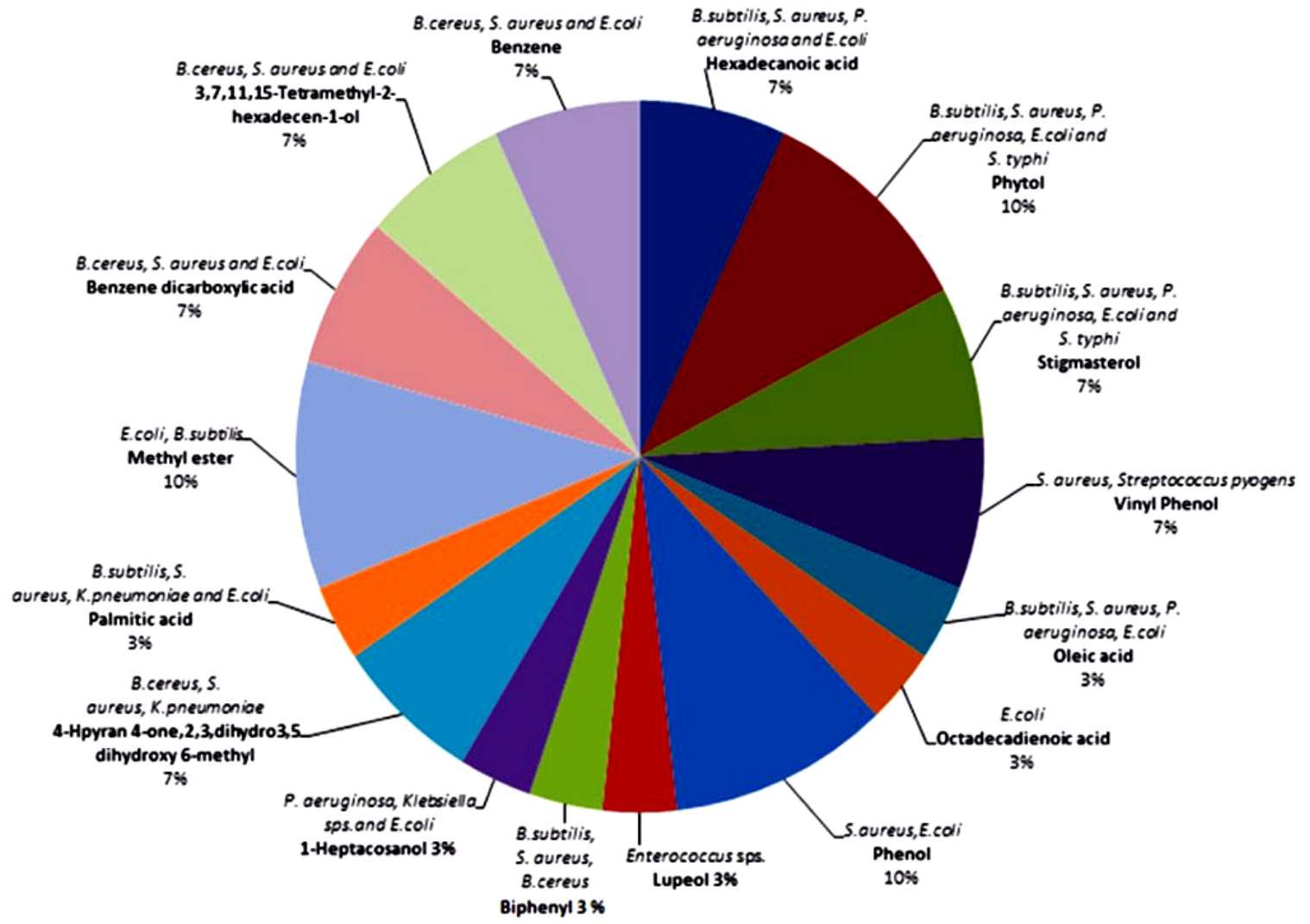

Figure 3. Phytochemicals displaying anti-microbial activity. 
Table 1. Mode of action of plant secondary metabolites

\begin{tabular}{|c|c|c|c|}
\hline S. No & $\begin{array}{l}\text { Secondary } \\
\text { metabolite }\end{array}$ & Mode of action & Reference \\
\hline 1. & Essential oils & $\begin{array}{l}\text { 1. Membrane disruption through lipophilic products. } \\
\text { 2. Quorum sensing inhibition. } \\
\text { 3. Expansion of membrane, increase of fluidity and } \\
\text { permeability of membrane, disturbance of membrane } \\
\text { embedded proteins, respiratory inhibition and alteration } \\
\text { in processes of ion transport in both Gram-positive and } \\
\text { Gram-negative bacteria. }\end{array}$ & $\begin{array}{l}{[124][125]} \\
{[57]} \\
{[126-129]}\end{array}$ \\
\hline 2. & Polyphenols & $\begin{array}{l}\text { 1. Bind to bacterial enzymes such as dihydrofolate } \\
\text { reductase and gyrases, which inhibit supercoiling activity } \\
\text { of E.coli. They bind to bacterial DNA which mediates } \\
\text { DNA cleavage and bacterial growth stasis by inducing } \\
\text { topoisomerase IV enzyme. } \\
2 \text {. Polyphenols affect intestinal Microbiota by mod- } \\
\text { ifying their active form or by changing the composition } \\
\text { of the intestinal microbiota probably inhibiting patho- } \\
\text { genic bacteria and enriching beneficial bacteria. } \\
\text { 3. Polyphenols and terpenoids possess strong binding } \\
\text { affinity to proteins and glycoproteins owing to their li- } \\
\text { pophilicity which is responsible for their great affinity for } \\
\text { cell membrane and can permeate through cell wall lead- } \\
\text { ing to leakage of cell contents. } \\
4 \text {. Curcumin induces ROS, membrane pore formation, } \\
\text { inhibition of morphogenetic switch and biofilm formation } \\
5 \text {. Resveratrol isolated from grapes was found to in- } \\
\text { duce apoptosis. } \\
6 \text {. Polyphenols and Terpenoids inhibit biofilm forma- } \\
\text { tion by disturbing the cytoplasmic membrane integrity of } \\
\text { bacteria affecting the electron transport chain, changing } \\
\text { the pH homeostasis, disrupting the proton motive force } \\
\text { and coagulation of cell contents(Lamiaceae, Asteraceae). }\end{array}$ & $\begin{array}{l}{[15]} \\
{[119][131][132]} \\
{[119][131][132]} \\
{[133]}\end{array}$ \\
\hline 3. & Phenols & $\begin{array}{l}\text { 1. Phenol damages the external membrane of the bac- } \\
\text { terial wall by disturbing the organization of the mem- } \\
\text { brane by binding at specific sites. } \\
2 \text {. Phenols exhibit their action on bacterial spores by } \\
\text { destabilizing the structure in spores. } \\
\text { 3. The phenol mechanism may even operate on nuc- } \\
\text { leus at chromosome level. } \\
4 \text {. Inhibition of enzymes through reactions with sulf- } \\
\text { hydryl groups on the proteins through non-specific inte- } \\
\text { racions. } \\
5 \text { Phenols and phenolic acids destruct the cell } \\
\text { by change in shape and size. } \\
6 \text {. Affect multiple target sites, decrease in cytoplasmic } \\
\text { pH and cell wall disruption. } \\
7 \text {. Phenolics and flavonoids were found to inhibit cell } \\
\text { wall and/or membrane formation(Fabaceae). } \\
8 \text {. Biofilm inhibition (Myrtaceae and Juglandaceae). }\end{array}$ & $\begin{array}{l}{[81]} \\
{[81]} \\
{[81]} \\
{[15]} \\
{[15]} \\
{[135]} \\
{[95]} \\
{[136]}\end{array}$ \\
\hline 4. & Alkaloids & $\begin{array}{l}\text { 1. Alkaloids show their mode of action either by af- } \\
\text { fecting cell division, Respiratory inhibition and enzyme } \\
\text { inhibition in bacteria, Bacterial membrane disruption or } \\
\text { affecting virulence genes. } \\
2 \text {. Toxic mechanisms of action of alkaloids arise due } \\
\text { to enzymatic alterations which affect the physiological } \\
\text { processes. They intercalate with nucleic acids inhibiting } \\
\text { DNA synthesis and repair mechanisms. } \\
\text { 3. An alkaloid berberine obtained from barberry plant } \\
\text { was found to exhibit its mode of action through DNA }\end{array}$ & $\begin{array}{l}{[137]} \\
{[138-140]}\end{array}$ \\
\hline
\end{tabular}




\begin{tabular}{|c|c|c|c|}
\hline & & $\begin{array}{l}\text { binding, inhibition of CDR1, Induction of apoptosis. } \\
4 \text {. Many members of the Solanaceae have Steroidal } \\
\text { alkaloids such as solanine and tomatine, which form } \\
\text { complexes with the cholesterol present in biomembranes } \\
\text { leading to membrane disruption by forming holes on } \\
\text { biomembranes rendering the cell leaky. } \\
5 \text {. Phenanthridineisoquinoline alkaloid was found to } \\
\text { act by inhibiting nucleic acid synthesis by targeting dihy- } \\
\text { drofolate reductase. } \\
6 \text {. Inhibit bacterial adherence to the surface of teeth, } \\
\text { exerting an anti-plaque action by perturbing bacterial } \\
\text { FtsZ Z-ring formation and inhibiting bacterial cytokinesis } \\
\text { (Piperaceae, Rubiaceae, Berberidaceae and Apocyna- } \\
\text { ceae). }\end{array}$ & $\begin{array}{l}{[88]} \\
{[116]}\end{array}$ \\
\hline 5. & Flavonoids & $\begin{array}{l}\text { 1. Flavones form complexes with bacterial cell walls, } \\
\text { extracellular and soluble proteins which induce microbial } \\
\text { cell membrane perturbations. 'B' ring of the flavonoids } \\
\text { was identified to play a role in intercalation, which shows } \\
\text { their inhibitory action on DNA and RNA synthesis. } \\
2 \text {. Flavones, Flavonoids, and Flavonols form com- } \\
\text { plexes with bacterial cell wall, extracellular proteins and } \\
\text { soluble proteins. They disrupt cell membranes. } \\
\text { 3. Flavonoids show their mode of action either by } \\
\text { membrane disruption, Biofilm inhibition, Inhibition of } \\
\text { cell envelope synthesis, Inhibition of nucleic acid synthe- } \\
\text { sis, chelation of metal ions or Inhibition of bacterial tox- } \\
\text { ins. } \\
4 \text {. Isoquercitirin isolated from Starwart was known for } \\
\text { membrane disruption. } \\
5 \text {. A Flavonoid, Cathechin isolated from Green tea } \\
\text { was found to cause cell wall damage. } \\
6 \text {. A Carotenoid, Lycopene isolated from Tomato } \\
\text { was known to cause membrane damage by inducing fun- } \\
\text { gal apoptosis. } \\
7 . \quad \text { Quercetin was found to inhibit ATAase enzyme } \\
\text { activity by binding to GyrB subunit of E. coli DNA gy- } \\
\text { rase. } \\
8 \text {. Quercetin was also reported to increase the per- } \\
\text { meability of the inner bacterial membrane. } \\
\text { 9. Flavonoids were found to Inhibit DNA gyrase, cell } \\
\text { membrane function and bacterial energy metabolism by } \\
\text { Interacting with DNA helicases, proteins essential for } \\
\text { DNA replication, repair and recombination and to pre- } \\
\text { vent dNTPs binding. They also inhibit PriA helicase ac- } \\
\text { tivity of S. aureus. They damage the lipid layer of the } \\
\text { membrane and biofilm inhibition and binding enterotoxin } \\
\text { B (Camellia sinensis and Poaceae). }\end{array}$ & $\begin{array}{l}{[142]} \\
{[143]} \\
{[144-146]} \\
{[148]} \\
{[116]}\end{array}$ \\
\hline 6. & Tannins & $\begin{array}{l}\text { 1. Tannins suppress microbial metabolism by block- } \\
\text { ing proteolytic macerating enzyme production which } \\
\text { inhibit bacterial cell proliferation. Tannins have the abil- } \\
\text { ity to inactivate microbial adhesins, enzymes, cell } \\
\text { envelope transport proteins, etc. which show their anti- } \\
\text { microbial action by stimulating phagocytic cells, } \\
\text { host-mediated tumor activity and a wide range of an- } \\
\text { ti-infective actions. Condensed tannins bind to cell walls } \\
\text { of ruminal bacteria, thereby inducing protease activity } \\
\text { and bacterial stasis. } \\
2 \text {. They form complexes with proteins by covalent and } \\
\text { non-covalent interactions. They also form complexes } \\
\text { with polysaccharides.They bind to the cell walls of ru- } \\
\text { minal bacteria, inhibiting growth, and protease activity. }\end{array}$ & [15] \\
\hline
\end{tabular}




\begin{tabular}{|c|c|c|c|}
\hline & & $\begin{array}{l}\text { 3. Non-flavonid polyphenol groups i.e phenolic acids, } \\
\text { stilbenes, coumarins and tannins were found to exhibit } \\
\text { induced morphological changes in bacterial cells leading } \\
\text { to an irregular shape with a wrinkled surface and induced } \\
\text { leakage of cytoplasmic components and inhibit bacterial } \\
\text { adhesion and prevent biofilm formation. They alter the } \\
\text { fatty acid composition and disruption of the outer mem- } \\
\text { brane of the cell (Poaceae and Rubiaceae). }\end{array}$ & [116] \\
\hline 7. & Terpenoids & $\begin{array}{l}\text { 1. Inhibit Calcium stress and Biofilm formation. } \\
\text { 2. Perturbation of cytoplasmic permeases, Inhibition } \\
\text { of ergosterol biosynthesis, Interference with the integrity } \\
\text { of the cell membrane and biofilm inhibition. } \\
\text { 3. In Cupressaceae, Monoterpenes and sesquiterpenes } \\
\text { were found to exhibit Quorum sensing/biofilm inhibition. } \\
\text { 4. Caffeic acids obtained from Tarragon were known } \\
\text { to inhibit biofilms. } \\
5 \text {. In Lamiaceae, terpenes/terpenoids, flavonoids were } \\
\text { found to inhibit cell wall and/or membrane formation. } \\
6 \text {. In Lauraceae, Aldehydes, aromatic alcohols, ter- } \\
\text { penoids, acid and derivatives were found to inhibit cell } \\
\text { wall and/or membrane formation. } \\
7 \text {. In Myrtaceae, Monoterpenes and flavonoids were } \\
\text { found to exhibit Quorum sensing/biofilm inhibition. } \\
\text { 8. In Zingiberaceae, Monoterpenes and flavonoids } \\
\text { were found to inhibit cell wall and/or membrane forma- } \\
\text { tion. } \\
\text { 9. Lamiaceae, Euphorbiaceae, Verbenaceae, Orchi- } \\
\text { daceae, Terpenoids were found to exhibit Anti-biofilm } \\
\text { and Anti-QS activities. }\end{array}$ & $\begin{array}{l}\text { [96] [97] } \\
{[98][97][99][100]} \\
{[95]} \\
{[150]} \\
{[95]} \\
{[95]} \\
{[95]} \\
{[95]} \\
{[116]}\end{array}$ \\
\hline 8. & Quinones & $\begin{array}{l}\text { Quinones block the cellular processes by inactiva- } \\
\text { tion of proteins or by forming complexes with aminoa- } \\
\text { cids of proteins causing antimicrobial effects. The main } \\
\text { targets of Quinones are the adhesins of microbial cell } \\
\text { surface, cell wall polypeptides and membrane-bound } \\
\text { enzymes. They also make the substrates unavailable to } \\
\text { the microorganism. } \\
2 \text { Irreversible complexes were formed with amino } \\
\text { acids in proteins. They attack surface adhesions and po- } \\
\text { lypeptides in the cell wall and membrane enzymes. They } \\
\text { sequester substrates required by the microorganisms. } \\
\text { They inactivate enzymes by binding to adhesins on the } \\
\text { microbial cell surface and binding to cell wall proteins, } \\
\text { thereby interacting with substrates, rendering them un- } \\
\text { available to the microorganism, complexing with metal } \\
\text { ions. }\end{array}$ & [151] \\
\hline 9. & Saponins & $\begin{array}{l}\text { 1. Alter the permeability of cell walls. } \\
\text { 2. They elicit changes in cell membranes } \\
\text { thereby changing the cell morphology, } \\
\text { which leads to cell lysis. }\end{array}$ & [103] \\
\hline 10. & Lectins & $\begin{array}{l}\text { 1. They bind reversibly to specific carbohydrates } \\
\text { without any chemical modification. } \\
2 \text {. The binding of plant lectins to bacterial cell wall } \\
\text { peptidoglycans (such as muramic acid, N-acetyl muramic } \\
\text { acid, N-acetyl glucosamine and muramyl dipeptides) are } \\
\text { responsible for its antibacterial activity. }\end{array}$ & $\begin{array}{l}{[105]} \\
{[107-109]}\end{array}$ \\
\hline
\end{tabular}


Table 2. Antimicrobial activity of bioactive compounds of medicinal plants against bacteria

\begin{tabular}{|c|c|c|c|c|c|}
\hline S.No & $\begin{array}{l}\text { Name of the } \\
\text { Plant }\end{array}$ & Bacterial pathogens affected & Nature of compound & Name of compound & $\begin{array}{l}\text { Ref- } \\
\text { erenc } \\
\text { e }\end{array}$ \\
\hline 1. & $\begin{array}{l}\text { Abelmoschas } \\
\text { moschatus }\end{array}$ & $\begin{array}{l}\text { Bacillus subtilis, } \\
\text { Staphylococcus aureus, } \\
\text { Escherichia coli, Pseudomonas } \\
\text { aeruginosa, } \\
\text { Proteus vulgaris, } \\
\text { Salmonella enterica paratyphi } \\
\text { and } \\
\text { Candida albicans }\end{array}$ & $\begin{array}{l}\text { Hydrocarbon } \\
\text { Carboxylic acid } \\
\text { Alcohol }\end{array}$ & $\begin{array}{l}\text { Tetradecane } \\
\text { Tridecanoic Acid } \\
\text { 1-Octadecanol }\end{array}$ & $\begin{array}{l}{[152]} \\
{[153]}\end{array}$ \\
\hline 2. & $\begin{array}{l}\text { Abrus preca- } \\
\text { torius }\end{array}$ & Staphylococcus aureus & $\begin{array}{l}\text { Diterpene } \\
\text { Sesquiterpenoid } \\
\end{array}$ & $\begin{array}{l}\text { Phytol } \\
\beta \text {-lonone }\end{array}$ & {$[154]$} \\
\hline 3. & $\begin{array}{l}\text { Albizia adian- } \\
\text { thifolia }\end{array}$ & $\begin{array}{l}\text { Pseudomonas aeruginosa, } \\
\text { Bacillus subtilis }\end{array}$ & $\begin{array}{l}\text { Acid } \\
\text { Sterol }\end{array}$ & $\begin{array}{l}\text { oleic acid } \\
\text { chondrillasterol }\end{array}$ & [155] \\
\hline 4. & $\begin{array}{l}\text { Aloe vera (L.), } \\
\text { Calendula } \\
\text { officinalis L. } \\
\text { and Matricaria } \\
\text { recutita L. }\end{array}$ & $\begin{array}{l}\text { Escherichia coli, } \\
\text { Pseudomonas aeruginosa and } \\
\text { Staphylococcus aureus }\end{array}$ & $\begin{array}{l}\text { Flavonoids and sapo- } \\
\text { nins }\end{array}$ & $\begin{array}{l}\text { camphene , } \\
\text { limonene } 1,8 \text {-cineole, } \\
\text { camphor , and } \alpha \text {-pinene , } \\
\text { where } \alpha \text {-bisabolol } \\
\text { oxide }\end{array}$ & {$[156]$} \\
\hline 5. & $\begin{array}{l}\text { Anabasis are- } \\
\text { tioïdes Coss. } \\
\text { \& Moq. }\end{array}$ & $\begin{array}{l}\text { Staphylococcus aureus, Bacil- } \\
\text { lussubtilis , Listeria innocua, } \\
\text { Escherichia coli K12, Protéus } \\
\text { mirabilis and Pseudomonas } \\
\text { aeruginosa }\end{array}$ & $\begin{array}{l}\text { Polyphenols and Tan- } \\
\text { nins }\end{array}$ & $\begin{array}{l}\text { cathechic tannins, sapo- } \\
\text { nins, sterols and phenolic } \\
\text { compounds }\end{array}$ & {$[157]$} \\
\hline 6. & $\begin{array}{l}\text { Aristolochia } \\
\text { krysagathra }\end{array}$ & $\begin{array}{l}\text { Bacillus subtilis, } \\
\text { Proteus vulgaris }\end{array}$ & Terpene alcohol & $\begin{array}{l}\text { 3,7,11,15-Tetramethyl-2- } \\
\text { hexadecen-1-ol }\end{array}$ & $\begin{array}{l}{[158]} \\
{[159]}\end{array}$ \\
\hline 7. & $\begin{array}{l}\text { Bauhinia } \\
\text { nakhonpha- } \\
\text { nomensis }\end{array}$ & $\begin{array}{l}\text { Staphylococcus aureus, Esche- } \\
\text { richia coli, Salmonella typhi, } \\
\text { Vibrio cholerae }\end{array}$ & Phenolic compound & Phenol & [160] \\
\hline 8. & $\begin{array}{l}\text { Bidens sul- } \\
\text { phurea, Bidens } \\
\text { pilosaand } \\
\text { Tanacetum } \\
\text { vulgare }\end{array}$ & $\begin{array}{l}\text { Staphylococcus aureus, Ente- } \\
\text { rococcusfaecalis , Escherichia } \\
\text { coli , and Pseudomonas aeru- } \\
\text { ginosa }\end{array}$ & $\begin{array}{l}\text { Flavonoids and terpe- } \\
\text { noids }\end{array}$ & $\begin{array}{l}\text { artemetin, } \beta \text {-sitosterol, } \\
\text { 5-methylheptan- } \\
\text { 2-amine, isohumulone, } \\
\text { costunolide, tridecanoic } \\
\text { acid, and octadecanoic acid } \\
\text { methyl ester }\end{array}$ & [161] \\
\hline 9. & $\begin{array}{l}\text { Boesenbergia } \\
\text { rotunda }\end{array}$ & $\begin{array}{l}\text { Escherichia coli, } \\
\text { Helicobacter pylori, Staphylo- } \\
\text { coccus aureus, Staphylococcus } \\
\text { epidermis }\end{array}$ & $\begin{array}{l}\text { Biphenyls } \\
\text { Biphenyls }\end{array}$ & $\begin{array}{l}\text { 3'-hydroxy-5-methoxy-3,4- } \\
\text { Methylenedioxybiphenyl } \\
\text { 3'-hydroxy-5,5'-dimethoxy } \\
\text {-3,4-methylenedioxybiphen } \\
\text { yl }\end{array}$ & [162] \\
\hline 10. & $\begin{array}{l}\text { Broussonetia } \\
\text { luzonica }\end{array}$ & Staphylococcus aureus & $\begin{array}{l}\text { Glycerol ester } \\
\text { Alkane }\end{array}$ & $\begin{array}{l}\text { Propanetriol monoacetate } \\
\text { Tetracosane }\end{array}$ & [163] \\
\hline 11. & $\begin{array}{l}\text { Bruguiera } \\
\text { cylindrica }\end{array}$ & $\begin{array}{l}\text { Escherichia coli, } \\
\text { Klebsiella pneumonia, Staphy- } \\
\text { lococcus aureus, Pseudomonas } \\
\text { aeruginosa, } \\
\text { Proteus mirabilis }\end{array}$ & $\begin{array}{l}\text { Diterpene } \\
\text { Phenol }\end{array}$ & $\begin{array}{l}\text { 2-Cyclopenten-1-one, } \\
\text { 2-hydroxy Phenol }\end{array}$ & $\begin{array}{l}{[164]} \\
{[164-} \\
{[167]}\end{array}$ \\
\hline
\end{tabular}




\begin{tabular}{|c|c|c|c|c|c|}
\hline 12. & $\begin{array}{l}\text { Calanthe trip- } \\
\text { licata }\end{array}$ & $\begin{array}{l}\text { Proteus vulgaris and } \\
\text { Klebsiella pneumoniae }\end{array}$ & Flavanoid & $\begin{array}{l}\text { 4H-Pyran-4-one, } \\
\text { 2,3-dihydro-3,5- dihy- } \\
\text { droxy-6-methyl }\end{array}$ & $\begin{array}{l}{[168]} \\
{[169]}\end{array}$ \\
\hline 13. & $\begin{array}{l}\text { Ceratonia } \\
\text { siliqua }\end{array}$ & $\begin{array}{l}\text { Pectobacterium atrosepticum, } \\
\text { Listeria monocytogenes, } \\
\text { Salmonella enteritidis, } \\
\text { Brocthrix thermosphacta }\end{array}$ & $\begin{array}{l}\text { Alcohol } \\
\text { Triterpenoid alcohol } \\
\text { Isoflavone } \\
\text { Phenol } \\
\text { Flavanone } \\
\text { Polyphenol }\end{array}$ & $\begin{array}{l}\text { n-nonadecanol } \\
\text { Lupeol } \\
\text { Genistein } \\
\text { Geraldone } \\
\text { Liquiritigenin } \\
\text { Epigallocatec } \\
\text { hin-3-gallate }\end{array}$ & [170] \\
\hline 14. & $\begin{array}{l}\text { Curcuma lon- } \\
\text { ga }\end{array}$ & $\begin{array}{l}\text { Listeria monocytogenes, } \\
\text { Staphylococcus aureus, } \\
\text { Bacillus cereus, } \\
\text { Micrococcus flavus, } \\
\text { Pseudomonas aeruginosa, } \\
\text { Escherichia coli, Aspergillus } \\
\text { flavus, } \\
\text { A. ochraceus, } \\
\text { A. niger, Penicillium ochroch- } \\
\text { loron, P. } \\
\text { funiculosum and Candida al- } \\
\text { bicans }\end{array}$ & $\begin{array}{l}\text { Carboxylic acid } \\
\text { Ester }\end{array}$ & $\begin{array}{l}\text { Benzenedi carboxylic acid, } \\
\text { di-isooctyl ester }\end{array}$ & $\begin{array}{l}{[171]} \\
{[172]}\end{array}$ \\
\hline 15. & $\begin{array}{l}\text { Cyperus ro- } \\
\text { tundus }\end{array}$ & $\begin{array}{l}\text { Staphylococcus aureus, Esche- } \\
\text { richia coli, } \\
\text { Bacillus Subtilis, } \\
\text { Pseudomonas aeruginosna and } \\
\text { Proteus vulgaris }\end{array}$ & Terpene alcohol & $\begin{array}{l}\text { 3,7,11,15-Tetramethyl-2- } \\
\text { hexadecen-1-ol }\end{array}$ & $\begin{array}{l}{[158]} \\
{[159]}\end{array}$ \\
\hline 16. & $\begin{array}{l}\text { Eupatorium } \\
\text { odoratum }\end{array}$ & $\begin{array}{l}\text { Staphylococcus aureus and } \\
\text { Escherichia coli }\end{array}$ & Phenol & 1-heptacosanol & [173] \\
\hline 17. & $\begin{array}{l}\text { Eupatorium } \\
\text { triplinerve }\end{array}$ & $\begin{array}{l}\text { Salmonella typhi, } \\
\text { Shigella sonnei }\end{array}$ & $\begin{array}{l}\text { Alcohol } \\
\text { Steroid } \\
\text { Acid } \\
\text { Ester } \\
\text { Hydrocarbon } \\
\text { Heterocyclic } \\
\text { compound }\end{array}$ & $\begin{array}{l}\text { 19-D-Torulosol } \\
\text { Stigmasta-5,22-diene, 3- } \\
\text { methoxy-,(3.beta.,22E) } \\
\text { 1,2-Benzenedicarboxylic } \\
\text { Acid } \\
\text { 9,12-Octadecadienoic } \\
\text { acid, methyl ester } \\
\text { 2,6,10-trimethyl,14- } \\
\text { ethylene-14-pentadecane } \\
\text { 2(4H)-Benzofuranone, } \\
\text { 5,6,7,7a tetrahydro- } \\
\text { 4,4,7 }\end{array}$ & [174] \\
\hline
\end{tabular}




\begin{tabular}{|c|c|c|c|c|c|}
\hline & & & Phenol & $\begin{array}{l}\text { ) } \\
\text { Phenol, } \\
\text { 5-methyl-2-(1-Methylethyl } \\
\text { ) }\end{array}$ & \\
\hline 18. & Ficus religiosa & $\begin{array}{l}\text { E.coli, } \\
\text { Pseudomonas aeruginosa, } \\
\text { Staphylococcus aureus }\end{array}$ & Flavanoid & $\begin{array}{l}\text { 4H-Pyran-4-one, } \\
\text { 2,3-dihydro-3,5- dihy- } \\
\text { droxy-6-methyl }\end{array}$ & $\begin{array}{l}{[168]} \\
{[169]}\end{array}$ \\
\hline 19. & $\begin{array}{l}\text { Hugonia mys- } \\
\text { tax }\end{array}$ & $\begin{array}{l}\text { E.coli, Proteus vulgaris, Pseu- } \\
\text { domonas aeruginosa, Salmo- } \\
\text { nella typhi, } \\
\text { Vibrio parahaemolyticus and } \\
\text { Vibrio vulnificus }\end{array}$ & $\begin{array}{l}\text { Aldehyde compound } \\
\text { Phenolic compound } \\
\text { Coumaran compound }\end{array}$ & $\begin{array}{l}\text { 2-Furancarboxaldehyde ,5- } \\
\text { (hydroxymethyl) } \\
\text { 2-Methoxy-4-vinylphenol } \\
\text { Benzofuran, 2,3-dihydro }\end{array}$ & [175] \\
\hline 20. & $\begin{array}{l}\text { Isodon rugo- } \\
\text { sus }\end{array}$ & $\begin{array}{l}\text { Staphylococcus aureus, } \\
\text { E. coli, } \\
\text { B. cereus, } \\
\text { K. pneumonia, } \\
\text { Salmonella typhi }\end{array}$ & $\begin{array}{l}\text { Carboxylic acid } \\
\text { Alcohol } \\
\text { Triterpene } \\
\text { Diterpene } \\
\text { Ester } \\
\text { Ketone } \\
\text { Ketone } \\
\text { Ester } \\
\text { Ester } \\
\text { Phytosterol } \\
\end{array}$ & $\begin{array}{l}\text { Palmitic acid } \\
\text { Hinokiol } \\
\alpha \text {-amyrin } \\
\text { Phytol } \\
\text { Ethyl linolate } \\
\text { Hinokione } \\
\text { Cyclohexanone } \\
\text { Methyl palmitate } \\
\text { Ethyl palmitate } \\
\text { Stigmasterol acetate }\end{array}$ & [176] \\
\hline 21. & $\begin{array}{l}\text { Michelia } \\
\text { champaca }\end{array}$ & $\begin{array}{l}\text { Aeromonas hydrophila, Esche- } \\
\text { richia coli, } \\
\text { Edwardsiella tarda, Flavobac- } \\
\text { terium spp., } \\
\text { Klebsiella pneumonia, } \\
\text { Salmonella typhi, } \\
\text { Vibrio alginolyticus, } \\
\text { V. parahaemolyticus, } \\
\text { V. cholerae and } \\
\text { Pseudomonas aeruginosa }\end{array}$ & $\begin{array}{l}\text { Acid } \\
\text { Ester }\end{array}$ & $\begin{array}{l}\text { 5,8,11,14-eicosatetraenoic } \\
\text { acid } \\
\text { methyl ester, (all Z)- }\end{array}$ & [177] \\
\hline 22. & $\begin{array}{l}\text { Ocimum } \\
\text { sanctum }\end{array}$ & $\begin{array}{l}\text { Salmonella enteritica, } \\
\text { Vibrio parahaemolyticus, } \\
\text { Escherichia coli, } \\
\text { Staphylococcus aureus, } \\
\text { Escherichia coli and } \\
\text { Listeria monocytogenes }\end{array}$ & $\begin{array}{l}\text { Sesquiterpene alcohol } \\
\text { Alcohol }\end{array}$ & $\begin{array}{l}\text { Farnesol } \\
\text { Geranylgeraniol (Diter- } \\
\text { pene) }\end{array}$ & [178] \\
\hline 23. & Olea europaea & $\begin{array}{l}\text { Campylobacter jejuni, } \\
\text { Helicobacter pylori, } \\
\text { Staphylococcus aureus, Sal- } \\
\text { monella enteritidis, } \\
\text { Bacillus cereus, } \\
\text { Klebsiella pneumoniae, } \\
\text { Escherichia coli, } \\
\text { Enterococcus faecalis, Strep- } \\
\text { tococcus thermophilus and } \\
\text { Lactobacillus bulgaricus }\end{array}$ & Phenol & Hydroxytyrosol & [179] \\
\hline 24. & Piper longam & $\begin{array}{l}\text { Escherichia coli, } \\
\text { Bacillus megaterium, Staphy- } \\
\text { lococcus albus, Pseudomonas } \\
\text { aeruginosa }\end{array}$ & $\begin{array}{l}\text { Fatty alcohol } \\
\text { Aromatic hydrocarbon }\end{array}$ & $\begin{array}{l}\text { 8-Heptadecene } \\
\text { Naphthalene }\end{array}$ & [172] \\
\hline 25. & Plectranthus & Staphylococcus aureus, & Diterpene & Phytol & [180] \\
\hline
\end{tabular}




\begin{tabular}{|c|c|c|c|c|c|}
\hline & amboinicus & $\begin{array}{l}\text { Bacillus subtilis, } \\
\text { Staphylococcus epidermis, } \\
\text { Enterococcus faecalis, Esche- } \\
\text { richia coli, } \\
\text { Pseudomonas aeruginosa, } \\
\text { Klebsiella pneumonia, Strep- } \\
\text { tococcus mutans }\end{array}$ & $\begin{array}{l}\text { Palmitic acid } \\
\text { Sesquiterpenoid } \\
\text { Isoprenyl Phenol } \\
\text { Sesquiterpenes } \\
\text { Phytosterol }\end{array}$ & $\begin{array}{l}\text { Hexadecanoic acid } \\
\text { Neophytadiene } \\
\text { Carvacrol } \\
\text { Caryophyllene oxide } \\
\text { Stigmasterol }\end{array}$ & \\
\hline 26. & $\begin{array}{l}\text { Pterocarpus } \\
\text { angolensis }\end{array}$ & $\begin{array}{l}\text { Staphylococcus aureus, Ente- } \\
\text { robacter cloacae, } \\
\text { Entamoeba histolytica }\end{array}$ & $\begin{array}{l}\text { Acid } \\
\text { Ester } \\
\text { Hydrocarbon } \\
\text { Phytosteroid } \\
\text { Ketone }\end{array}$ & $\begin{array}{l}\text { Hexadecanoic acid } \\
\text { Methyl ester } \\
\text { Tetratriacontane } \\
\text { 7-dehydrodiosgenin } \quad \text { Frie- } \\
\text { delan-3-one }\end{array}$ & [155] \\
\hline 27. & Saudi propolis & $\begin{array}{l}\text { Bacillus subtilis, } \\
\text { Micrococcus, } \\
\text { Proteus vulgaris, } \\
\text { Pseudomonas aeruginosa, } \\
\text { Escherichia coli }\end{array}$ & Diterpenoid phenol & Totarol & {$[181]$} \\
\hline 28. & $\begin{array}{l}\text { Solanecio } \\
\text { mannii }\end{array}$ & $\begin{array}{l}\text { Staphylococcus aureus, Strep- } \\
\text { tococcus faecalis, } \\
\text { Bacillus cereus, } \\
\text { Pseudomonas aeruginosa, } \\
\text { Shigella dysenteriae, } \\
\text { Shigella flexneri, } \\
\text { Klebsiella pneumoniae } \\
\end{array}$ & Ester & Hexacosanol, acetate & [182] \\
\hline 29. & $\begin{array}{l}\text { Terminalia } \\
\text { arjuna }\end{array}$ & $\begin{array}{l}\text { Vibrio cholera, } \\
\text { Staphylococcus aureus and } \\
\text { Pseudomonas aeruginosa }\end{array}$ & Alcohol & $\begin{array}{l}\text { 2-Furanmethanol(Furfuryl } \\
\text { alcohol) }\end{array}$ & {$[172]$} \\
\hline 30. & $\begin{array}{l}\text { Zingiber offi- } \\
\text { cinale }\end{array}$ & $\begin{array}{l}\text { Staphylococcus aureus, Esche- } \\
\text { richia coli , } \\
\text { Pseudomonas aeruginosa, } \\
\text { Vibrio cholera, } \\
\text { Klebsiella spp., } \\
\text { Salmonella spp. }\end{array}$ & $\begin{array}{l}\text { Aldehyde } \\
\text { Sesquiterpenoid } \\
\text { Sesquiterpenoid } \\
\text { Sesquiterpene } \\
\text { Sesquiterpene } \\
\text { Alcohol } \\
\text { Cyclohexenones } \\
\text { Carboxylic acid } \\
\text { Ketone } \\
\text { Methoxy compound } \\
\text { Sulphonic compound }\end{array}$ & $\begin{array}{l}\text { Decanal } \\
\text { Ben- } \\
\text { zene,1-(1,5-dimethyl-4 } \\
\text { hexanyl)-4-methy- } \\
\text { a-Farnesene } \\
\text { 1,6,10 Dodeca- } \\
\text { trien-3-ol,3,7,11- 3,7,11- } \\
\text { Trimethyl } \\
\text { 6,10-Dodecadien-1-yn-3-ol } \\
\text { 3,7,11- Trimethyl } \\
\text { Spiro(4,5)dec-6-en-8- } \\
\text { one,1,7-dimethyl }\end{array}$ & {$[172]$} \\
\hline
\end{tabular}




\begin{tabular}{|c|c|c|c|c|c|}
\hline & & & & $\begin{array}{l}\text { (2,6,6-Trimethylcyclohex-1 } \\
\text { - enylmethanesulfonyl) } \\
\text { benzene }\end{array}$ & \\
\hline 31. & $\begin{array}{l}\text { Phyllanthus } \\
\text { amarus }\end{array}$ & $\begin{array}{l}\text { Bacillus cereus, } \\
\text { Bacillus subtilis, } \\
\text { Escherichia coli, } \\
\text { Klebsiellapneumoniae }\end{array}$ & $\begin{array}{l}\text { Acid } \\
\text { Ether }\end{array}$ & $\begin{array}{l}\text { Hexadecanic acid } \\
\text { dimethyl ether }\end{array}$ & {$[90]$} \\
\hline 32. & $\begin{array}{l}\text { Salacia } \quad O b- \\
\text { longa }\end{array}$ & $\begin{array}{l}\text { Staphylococcus aureus, Pseu- } \\
\text { domonas aeruginosa and Kleb- } \\
\text { siella pneumoniae }\end{array}$ & $\begin{array}{l}\text { Ester } \\
\text { Acid } \\
\text { Acid } \\
\text { Sterol }\end{array}$ & $\begin{array}{l}\text { Hexadecanoic acid } \\
\text { 3-hydroxy methyl ester } \\
\text { Tetradecanoic acid } \\
\text { 9-Octadecenoic acid } \\
\gamma \text {-sitosterol }\end{array}$ & [183] \\
\hline 33. & $\begin{array}{l}\text { Drimia san- } \\
\text { guinea, Ele- } \\
\text { phantorrhiza } \\
\text { elephantina, } \\
\text { Helichrysum } \\
\text { parony- } \\
\text { chioides, Se- } \\
\text { necio longif- } \\
\text { lorus }\end{array}$ & $\begin{array}{l}\text { Shigella flexneri, } \\
\text { Candida glabrata, } \\
\text { Trichophytonrubrum, } \\
\text { Trichophyton tonsurans }\end{array}$ & 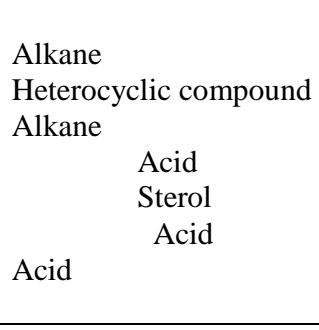 & $\begin{array}{l}\text { Dotriacontane, } \\
\text { Benzothiazole, } \\
\text { heptacosane, } \\
\text { phthalic acid, } \\
\text { stigmasterol, } \\
\text { hexanoic acid and } \\
\text { eicosanoic acid }\end{array}$ & [184] \\
\hline 34. & $\begin{array}{l}\text { Curcuma lon- } \\
\text { ga, } \\
\text { Punica gra- } \\
\text { natum, } \\
\text { Justicia adha- } \\
\text { toda, } \\
\text { Acalypha in- } \\
\text { dica }\end{array}$ & $\begin{array}{l}\text { Staphylococcusaureus, } \\
\text { Streptococcus pneumonia, } \\
\text { Mycobacterium tuberculosis }\end{array}$ & $\begin{array}{l}\text { Acid } \\
\text { Phenol } \\
\text { Alkaloid } \\
\text { Alkaloid } \\
\text { Flavonoid glycoside } \\
\text { Polyphenol } \\
\text { Acid }\end{array}$ & $\begin{array}{l}\text { Ascorbic acid, } \\
\text { curcumin, } \\
\text { vasicine, } \\
\text { piperine, } \\
\text { quercetin, } \\
\text { myricetin, } \\
\text { gallic acid }\end{array}$ & [185] \\
\hline 35. & Cleome ciliata & $\begin{array}{l}\text { Klebsiella pneumoniae, Strep- } \\
\text { tococcus pneumoniae, Staphy- } \\
\text { lococcus aureus, Salmonella } \\
\text { typhi, } \\
\text { Pseudomonas aeruginosa, } \\
\text { Rhizopus stolonifer, } \\
\text { Fusarium oxysporum, } \\
\text { Penicillium chrysogenum }\end{array}$ & $\begin{array}{l}\text { Flavonoids, } \\
\text { phenols, } \\
\text { terpenoids. }\end{array}$ & ----- & [186] \\
\hline 36. & $\begin{array}{l}\text { Syzygium cu- } \\
\text { mini, } \\
\text { Eucalyptus } \\
\text { globulus, } \\
\text { Aegle marme- } \\
\text { los, } \\
\text { Azadirachta } \\
\text { indica }\end{array}$ & $\begin{array}{l}\text { Staphylococcus aureus, } \\
\text { Escherichia coli }\end{array}$ & Phenols & ----- & [187] \\
\hline 37. & $\begin{array}{l}\text { Mespilus } \\
\text { germanica }\end{array}$ & $\begin{array}{l}\text { Staphylococcus aureus, } \\
\text { Staphylococcus epidermidis, } \\
\text { Streptococcus pneumonia, } \\
\text { Enterococcus faecalis, } \\
\text { Salmonella typhi, } \\
\text { Salmonella paratyphi, } \\
\text { Escherichia coli, } \\
\text { Klebsiellapneumoniae, } \\
\text { Klebsiellapneumoniae, } \\
\text { Yersinia enterocolitica, } \\
\text { Serratiamarcescens, } \\
\text { Shigelladysenteriae, } \\
\text { Citrobacter freundii }\end{array}$ & $\begin{array}{l}\text { phenols, } \\
\text { flavonoids , } \\
\text { carotenoids }\end{array}$ & ----- & [188] \\
\hline 38. & Berberis & Enterococcus faecalis, & Diterpenes, & & [189] \\
\hline
\end{tabular}




\begin{tabular}{|c|c|c|c|c|c|}
\hline & aristata & $\begin{array}{l}\text { Staphylococcus aureus, Sta- } \\
\text { phylococcus epidermidis, } \\
\text { Escherichia coli, } \\
\text { Klebsiella pneumonia, } \\
\text { Pseudomonas aeruginosa, } \\
\text { Salmonella typhimurium, } \\
\text { Candida albicans }\end{array}$ & $\begin{array}{l}\text { Flavonoids, } \\
\text { Tannins }\end{array}$ & ----- & \\
\hline 39. & $\begin{array}{l}\text { Tinospora } \\
\text { cordifolia }\end{array}$ & Streptococcus mutans & $\begin{array}{l}\text { Quinones, polyphenols, } \\
\text { alkaloids, } \\
\text { flavonoids, tannins, } \\
\text { coumarins, terpenoids, } \\
\text { lectins, } \\
\text { and polypeptides }\end{array}$ & ----- & [190] \\
\hline 40. & $\begin{array}{l}\text { Laennecia } \\
\text { confusa }\end{array}$ & $\begin{array}{l}\text { MRSA } \\
\text { Staphylococcus aureus } \\
\text { K. pneumoniae }\end{array}$ & $\begin{array}{l}\text { Triterpenes } \\
\text { Saponins } \\
\text { Flavonoids } \\
\text { Tannins } \\
\end{array}$ & ----- & [191] \\
\hline 41. & $\begin{array}{l}\text { Psidium gui- } \\
\text { neense }\end{array}$ & MRSA & $\begin{array}{l}\begin{array}{l}\text { Tannins, flavonoids, } \\
\text { condensed } \\
\text { proantho- } \\
\text { cyanidins, leucoantho- } \\
\text { cyanidins and sugar }\end{array}\end{array}$ & ----- & [191] \\
\hline 42. & $\begin{array}{l}\text { Hydrastis } \\
\text { canadensis }\end{array}$ & MRSA & Alkaloid and flavonoid & ----- & [191] \\
\hline 43. & $\begin{array}{l}\text { C. circinalis a } \\
\text { revoluta }\end{array}$ & $\begin{array}{l}\text { \$t@phylococcus aureus, } \\
\text { MRSA }\end{array}$ & Biflavonoids & ----- & [191] \\
\hline 44. & $\begin{array}{ll}\begin{array}{l}\text { Abrus } \\
\text { peri }\end{array} & \text { schim- } \\
\end{array}$ & $\begin{array}{l}\text { Staphylococcus aureus, } \\
\text { MRSA }\end{array}$ & $\begin{array}{l}\text { Amorphaquinone and } \\
\text { pendulone }\end{array}$ & ----- & [191] \\
\hline 45. & $\begin{array}{l}\text { Bersama en- } \\
\text { gleriana } \\
\text { Gurke }\end{array}$ & $\begin{array}{l}\text { Citrobacter freundii, Entero- } \\
\text { bacter cloacae, Escherichia } \\
\text { coli, } \\
\text { Klebsiella pneumonia, Morga- } \\
\text { nella morganii, } \\
\text { Proteus mirabilis, } \\
\text { Pseudomonas aeruginosa, } \\
\text { Shigella dysenteriae, } \\
\text { Salmonella typhi, } \\
\text { Streptococcus faecalis, } \\
\text { Staphylococcus aureus, } \\
\text { Bacillus cereus, } \\
\text { Bacillus stearothermophilus, } \\
\text { Bacillus subtilis }\end{array}$ & $\begin{array}{l}\text { Flavonoids } \\
\text { Phenols } \\
\text { Triterpenes } \\
\text { Anthraquinones }\end{array}$ & ----- & [191] \\
\hline 46. & $\begin{array}{l}\text { Xanthium } \\
\text { strumarium }\end{array}$ & $\begin{array}{l}\text { MSSA, } \\
M R S A\end{array}$ & $\begin{array}{l}\text { Phenolic acids, flavo- } \\
\text { noids tannins, triterpi- } \\
\text { noids }\end{array}$ & ----- & [191] \\
\hline 47. & $\begin{array}{l}\text { Holoptelea } \\
\text { integrifolia }\end{array}$ & $\begin{array}{l}\text { Bacillus cerculences, Pseudo- } \\
\text { monas aeruginosa, Bacillus } \\
\text { subtilis, } \\
\text { Klebsiella aeruginosa, Staphy- } \\
\text { lococcus aureus, Escherichia } \\
\text { coli }\end{array}$ & $\begin{array}{ll}\text { Alkaloids, } & \text { flavonoids } \\
\text { tannins, } & \text { terpenoids, } \\
\text { glycosides } & \end{array}$ & ----- & [191] \\
\hline 48. & $\begin{array}{l}\text { Piper umbel- } \\
\text { latum }\end{array}$ & $\begin{array}{l}\text { E.coli, K. pneumoniae, } \\
\text { P. aeruginosa, } \\
\text { S. typhimurium, } \\
\text { Shigella flexneri, } \\
\text { E. faecalis, } \\
\text { S. aureus, } \\
\text { S.pyogenes, }\end{array}$ & $\begin{array}{l}\text { Flavonoid, alkaloid, } \\
\text { terpene, } \\
\text { and sterolclasses }\end{array}$ & ----- & [191] \\
\hline
\end{tabular}




\begin{tabular}{|c|c|c|c|c|c|}
\hline & & S. epidermidis & & & \\
\hline 49. & $\begin{array}{l}\text { Lemongrass, } \\
\text { oregano, ro- } \\
\text { semary thyme, } \\
\text { neem, tulsi, } \\
\text { aloe vera } \\
\text { bryophyllum }\end{array}$ & $\begin{array}{l}\text { Multi-drug resistant Staphylo- } \\
\text { coccus aureus, } \\
\text { K. pneumoniae, } \\
\text { E. coli }\end{array}$ & $\begin{array}{l}\text { Sugars, alkaloids, anth- } \\
\text { raquinones, glycosides } \\
\text { flavonoids tannins, ste- } \\
\text { roids, saponins, triter- } \\
\text { penoids, phlobatanins }\end{array}$ & ----- & [191] \\
\hline 50. & $\begin{array}{l}\text { Helicanthus } \\
\text { elastica }\end{array}$ & $\begin{array}{l}\text { A. hydrophila, } \\
\text { K. pneumoniae, } \\
\text { E.coli, } \\
\text { V. fischeri, } \\
\text { B. subtilis, } \\
\text { MRSA, } \\
\text { P. aeruginosa, } \\
\text { S. pyogenes }\end{array}$ & Phenolic composition & ----- & [191] \\
\hline 51. & $\begin{array}{l}\text { Ephedra pro- } \\
\text { cera }\end{array}$ & $\begin{array}{l}\text { Proteus vulgaris } \\
\text { P. aeruginosa } \\
\text { Enterobacter aerogenes } \\
\text { B. cereus } \\
\text { S. aureus }\end{array}$ & Phenolic compound & ----- & [191] \\
\hline 52. & $\begin{array}{l}\text { Blechnum } \\
\text { orientale Linn }\end{array}$ & $\begin{array}{l}\text { B. cereus, } \\
\text { Micrococcus luteus, } \\
\text { MSSA, } \\
\text { MRSA, } \\
\text { S. epidermidis }\end{array}$ & $\begin{array}{l}\text { Flavonoids, terpenoids, } \\
\text { Tannins }\end{array}$ & ----- & [191] \\
\hline 53. & Cocos nucifera & $\begin{array}{l}\text { S. aureus } \\
\text { MRSA }\end{array}$ & Procyanidins & ----- & [191] \\
\hline 54. & $\begin{array}{l}\text { Clausena } \\
\text { heptaphylla }\end{array}$ & $\begin{array}{l}\text { B. subtilis, } \\
\text { S. aureus, } \\
\text { B. cereus, } \\
\text { B. polymyxa, } \\
\text { B. megaterium, } \\
\text { E. faecalis, } \\
\text { S. typhi, } \\
\text { Klebsiella spp., } \\
\text { S. flexneri, } \\
\text { S. sonnei, } \\
\text { Proteus spp., } \\
\text { E. coli }\end{array}$ & $\begin{array}{l}\text { Flavonoids, alkaloids, } \\
\text { saponins, steroids, gly- } \\
\text { coside, carbohydrate }\end{array}$ & ----- & [191] \\
\hline 55. & $\begin{array}{l}\text { Pupalia lap- } \\
\text { pacea Juss }\end{array}$ & $\begin{array}{l}\text { P. aeruginosa, } \\
\text { S.aureus, } \\
\text { B. subtilis }\end{array}$ & $\begin{array}{ll}\text { Steroids, } & \text { glycosides, } \\
\text { saponins, } & \text { flavonoids, } \\
\text { alkaloids, } & \text { sugar and } \\
\text { phenol } & \end{array}$ & ----- & [191] \\
\hline 56. & $\begin{array}{l}\text { Tabernae- } \\
\text { montana al- } \\
\text { ternifolia }\end{array}$ & $\begin{array}{l}\text { B. subtilis, } \\
\text { S.aureus, } \\
\text { S. epidermidis, } \\
\text { E. col, } \\
\text { MRSA, } \\
\text { VRSA }\end{array}$ & $\begin{array}{l}\text { Alkaloids, flavonoids, } \\
\text { coumarins, saponins and } \\
\text { steroids }\end{array}$ & ----- & [191] \\
\hline 57. & $\begin{array}{l}\text { Chelidonium } \\
\text { majus Linn }\end{array}$ & MRSA & Alkaloids & ----- & [191] \\
\hline 58. & $\begin{array}{l}\text { Premna resi- } \\
\text { nosa }\end{array}$ & $\begin{array}{l}\text { S. aureus, } \\
\text { MRSA, } \\
\text { E. coli, } \\
\text { K. pneumoniae, } \\
\text { P. aeruginosa, }\end{array}$ & $\begin{array}{l}\text { Flavonoids, Anthraqui- } \\
\text { nones, Terpenoids, } \\
\text { Phenols, Alkaloids }\end{array}$ & ----- & [191] \\
\hline
\end{tabular}




\begin{tabular}{|c|c|c|c|c|c|}
\hline & & $\begin{array}{l}\text { S. typhi, } \\
\text { S. sonnei, } \\
\text { M. tuberculosis }\end{array}$ & & & \\
\hline 59. & $\begin{array}{l}\text { B. citriodora, } \\
\text { T. ferdinan- } \\
\text { diana, } \\
\text { C. australasi- } \\
\text { ca, L. ponti- } \\
\text { cum }\end{array}$ & $\begin{array}{l}\text { S. aureus, } \\
\text { E. coli, } \\
\text { B. cereus }\end{array}$ & Phenolic compounds & ----- & {$[191]$} \\
\hline 60. & $\begin{array}{l}\text { Terminalia } \\
\text { fagifolia }\end{array}$ & $\begin{array}{l}\text { S. aureus, } \\
\text { S.epidermidis, } \\
\text { S. epidermidis, } \\
\text { S. epidermidis }\end{array}$ & $\begin{array}{l}\text { Terpenoids, } \\
\text { glucocorticoids, flavo- } \\
\text { noids polyphenols }\end{array}$ & ----- & [191] \\
\hline 61. & $\begin{array}{l}\text { Moringa olei- } \\
\text { fera, } \\
\text { Matricaria } \\
\text { recutita }\end{array}$ & $\begin{array}{l}\text { P. aeruginosa, } \\
\text { Klebsiella spp., } \\
\text { E. coli, } \\
\text { Proteus mirabilis, Staphylo- } \\
\text { coccus spp. }\end{array}$ & $\begin{array}{l}\text { Alkaloids, polyphenols, } \\
\text { flavonoids, anthraqui- } \\
\text { nones, coumarins, tan- } \\
\text { nins, triterpenes, } \\
\text { sterols, saponins, and } \\
\text { some other secondary } \\
\text { metabolites. }\end{array}$ & ----- & [192] \\
\hline 62. & $\begin{array}{l}\text { Lasiosiphon } \\
\text { eriocephalus }\end{array}$ & $\begin{array}{l}\text { Klebsiella pneumonia, Esche- } \\
\text { richia coli, } \\
\text { Pseudomonas aeruginosa, } \\
\text { Staphylococcus aureus }\end{array}$ & $\begin{array}{l}\text { phenolics, tannins, fla- } \\
\text { vonoids }\end{array}$ & ----- & [193] \\
\hline 63. & $\begin{array}{lr}\text { Piper } & \text { nigrum } \\
\text { and } & \text { Piper } \\
\text { longum } & \\
\end{array}$ & Staphylococcus aureus & Alkaloid & Piperidine & {$[48]$} \\
\hline 64. & $\begin{array}{l}\text { Glycyrrhiza } \\
\text { glabra }\end{array}$ & $\begin{array}{l}\text { S. aureus, } \\
\text { M. tuberculosis }\end{array}$ & Flavonoids & Glabrol & {$[48]$} \\
\hline 65. & $\begin{array}{l}\text { Rauwolfia } \\
\text { serpentina }\end{array}$ & $\begin{array}{l}\text { Staphylococcus spp., Strepto- } \\
\text { coccus spp., and } \\
\text { Micrococcus spp., }\end{array}$ & Indole alkaloid & Reserpine & {$[48]$} \\
\hline 66. & $\begin{array}{l}\text { Lycopersicum } \\
\text { esculentum, } \\
\text { Solanum tu- } \\
\text { berosum }\end{array}$ & Staphylococcus aureus & Steroidal alkaloid & Tomatidine & [48] \\
\hline 67. & $\begin{array}{l}\text { Ipomoea } \quad \text { mu- } \\
\text { ricata }\end{array}$ & Escherichia coli & $\begin{array}{l}\text { Tricyclic ergot } \\
\text { alkaloid }\end{array}$ & Chanoclavine & {$[48]$} \\
\hline 68. & $\begin{array}{l}\text { Allium } \\
\text { sativum }\end{array}$ & $\begin{array}{l}\text { Staphylococcus } \\
\text { epidermidis, P. aeruginosa, } \\
\text { Streptococcus agalactiae }\end{array}$ & $\begin{array}{l}\text { Organosulfur } \\
\text { compound }\end{array}$ & Allicin & [48] \\
\hline 69. & Vitis vinifera & $\begin{array}{l}\text { Campylobacter jejuni, } \\
\text { M. smegmatis }\end{array}$ & Phenolic compound & Resveratrol & [48] \\
\hline 70. & $\begin{array}{l}\text { Terminalia } \\
\text { chebula }\end{array}$ & M. tuberculosis & Tannin & Chebulinic acid & [48] \\
\hline 71. & $\begin{array}{l}\text { Asphodelus } \\
\text { microcarpus }\end{array}$ & $\begin{array}{l}\text { S. aureus, E. coli, } \\
\text { P. aeruginosa, } \\
\text { C. albicans and } \\
\text { Botrytis cinerea }\end{array}$ & $\begin{array}{l}\text { Aryl coumarin gluco- } \\
\text { side } \\
\text { Aglycon }\end{array}$ & $\begin{array}{l}\text { asphodelin } \\
\text { 4'-O- } \beta \text {-Dglucoside } \\
\text { Asphodelin A }\end{array}$ & {$[48]$} \\
\hline
\end{tabular}

\section{Challenges and future perception:}

About $60 \%$ of the Earth's biomass is comprised of microbial species causing infectious diseases leading to mortality. Population across the world is facing threat to health by extraordinary diversity of these microbes in their genetic, metabolic and physiological activities. Plant secondary metabolites have demonstrated immense antimicrobial potential. Plants may prove to be a promising species selective alternative for these microbial pathogens [117]. It is hypothesized that plants do not produce highly potent inhibitors of specific microbial targets. It may be owing to the property of microbes to acquire resistance which forces plants to rely on nonspecific compounds [118]. Prasad [95] used a novel strategy using phylogenetic evidence to determine plant families with high representation of antimicrobial activity and potential source of antibacterial drug discovery. They reconstructed molecular phylo- 
geny of plant species displaying antibacterial activity and further mapped their mode of action against bacteria on phylogeny. They identified seven plant families viz. combretaceae, cupressaceae, Fabaceae, Lamiaceae, Lauraceae, Myrtaceae and Zinziberaceae with higher antibacterial potential. The mode of action of most of the phytochemicals was disruption of bacterial cell membrane or cell wall and inhibition of quorum sensing or biofilm production. They concluded that plant extracts from these families may prove to be promising leads for novel drug development. There are myriad reports of antimicrobial activity of plants, however, it is needed to identify and study the bioactive component responsible for the activity. Further it has to undergo efficacy and potency testing followed by scientific validation of its applications. Phytopharmaceuticals as an alternative to antibiotics would safeguard health issues and also ensure issues related to public health safety viz. presence of antibiotic residues in animal products and zoonotic threats. Herbal therapy has important considerations for safety issues, many phytoconstituents are biologically more active and however, they have concurrent disadvantages of toxicity, which has to be carefully standardized. The pharmacological activity of many phytoconstituents varies with its concentration and presence of other phytoconstituents. This may be synergistic or antagonistic, harmful or beneficial based on the interaction of phytoconstituents. There is a need to establish pharmacological activities of bioactive compounds individually or in combinations. Medicinal plants prove to be much cheaper, safer and have widely accepted health benefits. However, there is a need of exhaustive scientific validation, standardization and safety evaluation before commercialization.

Herbal therapy opens alternative avenues in the present situation to develop broad spectrum antibacterial herbal formulation from these natural resources for safeguarding several health issues [13]. The main constraints associated with application of phytocompounds is its being a complex blend of bioactive compounds and variation in composition due to several biological, processing, and storage factors. Further, the units of application or doses are not standardized [119]. Future research targeting their purification, understanding their mode of action, standardizing appropriate units of administration, compatibility with diet, toxicity, safety and stability assessment, as well as their pharmacodynamics and pharmacokinetic properties is required for establishing them as an effective alternate to antibiotics [120]. Phytotherapy may not replace use of antibiotics completely as treatment agents, however, it may be implemented as preventive and management therapy. To ensure long term sustainable development judicious use of antibiotics is obligatory. There is a need to strengthen and enforce the laws along with the policies pertaining to their uses.Plants have been considered as potential source of antimicrobial compounds, however, there are no antibiotics derived from plants which is surprising with large efforts devoted for mining the plant sources and their chemical defense against pathogens [121]. Barbieri [116] elucidated in their review that plant derived phytochemicals represent a possible source of effective, cheap and safe antimicrobial agents. However, much work needs to be conducted both in vitro and in vivo to ensure the selection of active and nontoxic antimicrobial phytochemicals. Phytotherapy was proven to be an effective and economical way for managing health of aquatic animals and can be used as a substitute to chemotherapy [122]. This application can also be used by researchers for control of various diseases in aquatic animals using phytochemicals [123].

Renewed scientific interest in plant-derived natural product-based drug discovery is evident from the research publications. Plants produce chemically highly diverse secondary metabolites with different biological functions and are still far from being exhaustively investigated. With the revived scientific interest in natural product-based drug discovery, novel approaches for the identification, characterization and understanding their mode of action have being developed, and that may address some of the challenges associated with drug development. In order to harvest its full potential, an interdisciplinary approach involving ethnopharmacological knowledge, botany, phytochemistry, and pharmacological testing strategies needs to be developed [9]. Establishment of phytocompounds as an alternative to antibiotics requires focus on understanding their mode of action, standardization of units of administration (dose optimization) along with safety, stability and toxicity profiles with their pharmacokinetic and pharmacodynamic properties. There are missing links which need to be investigated in order to elucidate their role for clinical application.

\section{Conclusion:}

Various components of plants were effectively used for treatment of many bacterial diseases since centuries. Several classes of bioactive compounds represent key compounds in the management of various diseases with potent in vitro activities. As phytochemicals of plants play a major role in maintenance of human health, effort to search for plant based antimicrobial agents is intensified by present day researchers. Pharmaceutical industries use a variety of phytochemical constituents either directly or indirectly. Plant derived products may potentially control microbial growth in diverse conditions and in the particular case of disease treatment, several studies have aimed to describe the chemical structures of these plant antimicrobials and the mechanisms which are involved in inhibition 
of microbial growth. Further investigations are needed to study the complex molecular mechanisms which are responsible for these synergistic interactions for developing new drug combinations against multi-drug resistant bacterial infections.

\section{Conflict of interest:}

The authors declare that they have no conflict of interest.

\section{Ethical approval:}

This article does not contain any studies with human participants or animals performed by any of the authors.

\section{References}

[1] Egamberdieva, D., Stephan Wirth, Undine Behrendt, Parvaiz Ahmad, Gabriele Berg. (2017). Antimicrobial activity of medicinal plants correlates with the proportion of antagonistic endophytes. Front Microbiol. 8: 199.

[2] Rios, J. L., Recio, M. C. (2005). Medicinal plants and antimicrobial activity. J Ethnopharmacol. 100(2005): 80-84.

[3] Schmidt, T. J., Khalid, S. A., Romanha, A. J., Alves, T. M., Biavatti, M. W., Brun, R., Costa, F. B. D., Castro, S. L. D., Ferreira, V. F., Lacerda, M. V. G. D., Lago, J. H. G., Leon, L. L., Lopes, N. P., Amorim, R. C. D. N., Niehues, M., Ogungbe, I. V., Pohlit, A. M., Scotti, M. T., Setzer, W. N., Soeiro, M. D. N. C., Steindel, M., Tempone, A. G. (2012). The potential of secondary metabolites from plants as drugs or leads against protozoan neglected diseases_part II. Curr Med Chem. 19: $2176-2228$.

[4] Si-Yuan Pan, Shu-Feng Zhou, Si-Hua Gao, Zhi-Ling Yu, Shuo-Feng Zhang, Min-Ke Tang, Jian-Ning Sun, Dik-Lung Ma, Yi-Fan Han, Wang-Fun Fong, Kam-Ming Ko. (2013). New Perspectives on How to Discover Drugs from Herbal Medicines: CAM's Outstanding Contribution to Modern Therapeutics. J Evid Based Complementary Altern Med. http://dx.doi.org/10.1155/2013/627375.

[5] Newman. (2008). Natural products as leads to potential drugs: an old process or the new hope for drug discovery? J Med Chem. 51: 2589-2599.

[6] Chen, S. L., Hua Yu, Hong-Mei Luo, Qiong Wu, Chun-Fang Li, André Steinmetz. (2016). Conservation andsustainable use of medicinal plants: problems, progress and prospects. 11: 37. DOI 10.1186/s13020-016-0108-7.

[7] Savoia. (2012). Plant derived antimicrobial compounds: Alternatives to antibiotics. Future Microbiol. 7: 979-990.

[8] Krishnananda, I. P., Amit, G. D., Dipika, A. P., Mahendra, S. D., Mangesh, P. M., Vaibhav, C. K. (2017). Phytochemicals: Extraction methods, identification and detection of bioactive compounds from plant extracts. J. Pharmacogn Phytochem. 6(1): 32-36.

[9] Atanasov, A. G., Waltenberger, B., Pferschy-Wenzig, E. M., Linder, T., Wawrosch, C., Uhrin, P., Temml,V., Wang, L., Schwaiger, S., Heiss, E. H., Rollinger, J. M., Schuster, D., Breuss, J. M., Bochkov, V., Mihovilovic, M. D., Kopp, B., Bauer, R., Dirsch, V. M., Stuppner, H. (2016). Discovery and resupply of pharmacologically active plant-derived natural products: A review. Biotechnol Adv. 33(8): 1582-1614. doi: 10.1016/j.biotechadv.2015.08.001.PMID: 26281720; PMCID: PMC4748402.

[10] WHO traditional medicine strategy, 2002-2005. www.who.int/medicines/library/trm/trm_stat_eng.pdf.

[11] Hossain, K., Hassan, M., Parvin, N., Hasan, M., Islam, S., Haque, A. (2012). Antimicrobial, cytotoxic and thrombolytic activity of Cassia senna Leaves (Family: Fabaceae). J. Appl. Pharm. Sci. 2(6): 186-190. https://www.japsonline.com/admin/ php/uploads/527_pdf.pdf.

[12] Gorniak, I., Bartoszewski, R., Kroliczewski, J.,2019. Comprehensive review of antimicrobial activities of plant flavonoids. Phytochem Rev. 18:241-272..https://doi.org/10.1007/s11101-018-9591-z.

[13] Dhama, K., Chakraborty,S., Tiwari,R., Verma,A.K., Saminathan,M.,Amarpal., Malik,Y.S.,Nikousefat, Z., Javdani, M., Khan, R.U., 2014. A concept paper on novel technologies boosting production and safeguarding health of humans and animals. Res. Opin. Anim. Vet. Sci., 4(7): 353-370.EISSN: 2223-0343.

[14] Mahima, Rahal, A., Deb, R., latheef, S. K., Samad, H. A. (2012). Immunomodulatory and therapeutic potentials of herbal, traditional/indigenious and ethnoveterinary medicines. Pak. J. Biol. Sci. 15: 754-774.

[15] Othman, L., Sleiman, A., Abdel-Massih, R. M. (2019). Antimicrobial Activity of Polyphenols and Alkaloids in Middle Eastern Plants. Front. Microbiol.10.911.doi: 10.3389/fmicb.2019.00911.

[16] Borges. (2016). New Perspectives on the Use of Phytochemicals as an Emergent Strategy to Control Bacterial Infections Including Biofilms. Molecules. 21(7). pii: E877. doi: 10.3390/molecules 21070877. PMID: 27399652. PMCID: PMC6274140.

[17] Tegos, G., Stermitz, F. R., Lomovskaya, O., Lewis, K. (2002). Multidrug pump inhibitors uncover remarkable activity of plant antimicrobials. Antimicrob Agents Chemother. 46, 3133-3141.

[18] Marchese, A., Shito, G. (2001). Resistance patterns of lower respiratory tract pathogens in Europe. Int. J. Antimicrob. Agents. 16: 25-29.

[19] Jinukuti, M. G., Giri, A. (2013). Antimicrobial activity of phytopharmaceuticals for prevention and cure of diseases. Ann Phy- 
tomed. 2(2): 28-46. ISSN 2278-9839.https://pdfs.semanticscholar.org/1cb6/f7aa8736d56af0a20ee705ed8f8b703c76e5.pdf.

[20] Pavle, M. Z., Vesna,V., Sasa, D., Zoran, Z., Marija, R., Aleksandra, C., Jaroslava, S. G., Milan, M., Jelena, V. (2018). Biological activity and chemical profile of Lavatera thuringiaca $L$. extracts obtained by different extraction approaches. Phytomedicine. 38(2018): 118-124.

[21] Zengin, G., Zaahira, A. E., Adriano, M., Mustafa, Abdullah, Y., Mohamad Fawzi, M. (2018). In vitro and in silico perspectives on biological and phytochemical profile of three halophyte species-A source of innovative phytopharmaceuticals from nature.Phytomedicine. 38(2018): 35-44.

[22] Zengin, G., Uysal, A., Aktumsek, A., Mocan, A., Mollica, A., Locatelli, M., Custodio, L., Neng, N. R., Nogueira, J. M. F., Aumeeruddy-Elalfi, Z., Mahomoodally, M. F. (2017). Euphorbia denticulata Lam.: A promising source of phyto-pharmaceuticals for the development of novel functional formulations. Biomed.Pharmacother. 87: 27-36.

[23] Shuma, F., Neelaiah Babu, G., Aman, D., Yiheyis, B. (2018). Phytochemical Investigation and Antimicrobial Study of leaf Extract of Plantago lanceolata. Nat. Prod. Chem. Res. 6(2): 1-8.

[24] Roy, S., Kiranmayee, Rao, Bhuvaneswari, Ch., Giri, A., Lakshmi Narasu, M. (2010). Phytochemical analysis of Andrographis paniculata extract and its antimicrobial activity. World J Microbiol Biotechnol. 26: 85-91.

[25] Chodisetti, B., Kiranmayee Rao, Archana Giri. (2013). Phytochemical analysis of Gymnema sylvestre and evaluation of its antimicrobial activity. Nat. Prod. Res. 27(6): 583-587.

[26] Feher, M., Schmidt, J. M. (2003). Property distributions: differences between drugs, natural products, and molecules from combinatorial chemistry. J Chem Inf Comput Sci. 43: 218-227.

[27] Helander, I. M., Alakomi, H. L., Latva-kala, K., Mattila-Sandholm, T., Pol, I., (1998). Characterization of the Actionof selected essential oil components on gram-negative bacteria. J. Agric. Food Chem. 46(9): 3590-3595. https://pubs.acs.org/doi/abs/10. 1021/jf980154m.https://doi.org/10.1021/jf980154m.

[28] Juven, B. J., Kanner, J., Schved, F., Weisslowicz, H. (1994). Factors that interact with the antibacterial action of thyme essential oil and its active constituents. J Appl Bacteriol. 76: 626-631.

[29] Bendich. (1989). Carotenoids and the immune response. J. Nutr. 119: 112-115.

[30] Henson, D. E., Block, G., Levin, M. (1991). Ascorbic acid biological function in relation to cancer. J Natl Cancer Inst. 83: 547-550.

[31] Ringer, T. V., Deloof, M. J., Winterrowd, G. E., Francom, S. F., Gaylor, S. K. (1991). Beta-carotenes effects on serum lipoproteins and immunologic indices in humans. Am. J. Clin. Nutr. 53: 688-694.

[32] Govindarajan, R., Vijayakumar, M., Pushpangadan, P. (2005). Antioxidant approach to disease management and the role of 'Rasayana' herbs of Ayurveda. J Ethnopharmacol. 99: 165-178.

[33] Tiwari, R., Chakraborty, S., Saminathan, M., Dhama, K., Singh, S. V. (2014). Ashwagandha (Withania somnifera): Role in safeguarding health, immunomodulatory effects, combating infections and therapeutic applications: A review. J. Biol. Sci. 14: 77-94.

[34] Nahrstedt, A., Hungeling, M., Petereit. (2006). Flavonoids from Acalypha indica.Fitoterapia. 77: 484-486.

[35] Rahal, A., Kumar, A., Singh, V., Yadav, B., Tiwari, R., Chakraborty, S., Dhama, K. (2014). Oxidative stress, prooxidants and antioxidants: The interplay. Biomed Res. Int. 10.1155/2014/761264.

[36] Ruberto, G., Baratta, M. T., Deans, S. G., Dorman, H. J. (2000). Antioxidant and antimicrobial activity of Foeniculum vulgare and Crithmum maritimum essential oils. Planta Med. 66: 687-693.

[37] Joe, B., Vijaykumar, M., Lokesh, B. R. (2004). Biological properties of curcumin—cellular and molecular mechanisms of action.Crit Rev Food Sci Nutr. 44: 97-111.

[38] Lee, J. H., Shim, J. S., Lee, J. S,, Kim, M. K., Chung, M. S., Kim, K. H. (2006). Pectin-like acidic polysaccharide from Panax ginseng with selective anti adhesive activity against pathogenic bacteria.Carbohydr. Res. 341: 1154-1163.

[39] Choi. (2008). Botanical characteristics, pharmacological effects and medicinal components of Korean Panax ginseng C A Meyer. Acta Pharmacol Sin. 29: 1109-1118.

[40] Akram, M., Shahab-Uddin., Ahmed, A., Usmanghani, K., Hannan, A., Mohiuddin, E., Asif, M., 2010. Curcuma longa and curcumin: A review article. Rom. J. Biol. Plant Biol. 55(2): 65-70. Bucharest. https://www.researchgate. net/publication/284415430.

[41] Kang, S., Min, H. (2012). Ginseng, the immunity boost: The effects of Panax ginseng on immune system. J Ginseng Res. 36: 354-368.

[42] Yoo, D. G., Kim. M. C., Park, M. K., Park, K. M., Quan, F. S. (2012). Protective effect of ginseng polysaccharides on influenza viral infection. PloS One. 7(3): e33678. https://doi.org/10.1371/journal.pone.0033678.

[43] Diao, W., Hu, Q., Zhang, H., Xu, J. (2014). Chemical composition, antibacterial activity and mechanism of action of essential oil from seeds of fennel (Foeniculum vulgare Mill.). Food control. 35: 109-116.https://doi.org/10.1016/j.foodcont.2013.06.056.

[44] Walsh. (2013). Investigating antibiotic resistance in non-clinical environments. Front Microbiol. 4: 9. 
[45] Dantas, G., Sommer, M. O. A., Oluwasegun, R. D., Church, G. M. (2008). Bacteria subsisting on antibiotics. Science. 320(5872): 100-103.

[46] Blair, J. M. A., Webber, M. A., Baylay, A. J., Ogbolu, D. O., Piddock, L. J. V. (2015). Molecular mechanisms of antibiotic resistance. Nat Rev Microbiol. 13: 42-51.

[47] Holmes, A. H., Moore, L. S. P., Sundsfjord, A., Steinbakk, M., Regmi, S., Karkey, A., Guerin, P. J., Piddock, L. J. V. (2016). Understanding the mechanisms and drivers of antimicrobial resistance. Lancet. 387: 176-187.

[48] Khameneh, B., Iranshahy, M., Soheili, V., Bazzaz, B. S. F. (2019). Review on plant antimicrobials: a mechanistic view point. Antimicrobial Resistance and Infection Control.8: 118.https://doi.org/10.1186/s13756-019-0559-6.

[49] Rollins, D. M., Joseph, S. W. (2000). Pathogenic Microbiology, University of Maryland, Basic Mechanisms of Antibiotic Action and Resistance.

[50] Dehghan, H., Sarrafi, Y., Salehi, P. (2016). Antioxidant and antidiabetic activities of 11 herbal plants From Hyrcania region.J Food Drug Anal. 24(1): 179-188. doi: 10.1016/j.jfda.2015.06.010. PMID: 28911402. DOI: 10.1016/j.jfda.2015.06.010.

[51] Akram, M., Hamid, A., Khalil, A., Ghaffar, A., Tayyaba, N., Saeed, A., Ali, M., Naveed, A. (2014). Review on medicinal uses, pharmacological, phytochemistry and immunomodulatory activity of plants. Int J Immunopathol Pharmacol., 27: 313-319.

[52] Silva Da, J. A. T., Yonekura, L., Kaganda, J., Mookdasanit, J., Nhut, D. T., Afach, G. (2005). Important secondarymetabolites and essential oils of species within the Anthemideae (Asteraceae). J Herbs Spices Med Plants.11: 1-46.

[53] French. (2005). Clinical impact and relevance of antibiotic resistance.Adv Drug Deliv Rev. 57(10): $1514-27$. https://doi.org/10.1016/j.addr.2005.04.005.PMID:15978698.DOI:10.1016/j.addr.2005.04.005.

[54] Basri, D. F., Fan, S. H. (2005). The potential of aqueous and acetone extracts of galls of Querus infectoria as antibacterial agents. Indian J. Pharmacol. 37(1): 26-29. XXXVIII Annual Conference of the XXXVIII Annual Conference of the Indian Pharmacological Society, December 28-30, 2005, Madras Medical College, Chennai (Preconference Workshop on 27-12-2005) orkshop on 27-12-2005).

[55] Nikaido. (2003). Molecular Basis of Bacterial Outer Membrane Permeability Revisited. Microbiol. Mol. Biol. Rev. 67(4): 593-656.

[56] Saranraj, P., Sivasakthivelan, P. (2012). Screening of antibacterial activity of the medicinal plant Phyllanthus amarus against urinary tract infection causing bacterial pathogens. Appl. J. Hygiene. 1(3): 19-24.

[57] Yap, P. S.X., Yiap, B. C., Ping, H. C., Lim, S. H.E. (2014). Essential oils, a new horizon in combating bacterial antibiotic resistance. Open Microbiol J. 8: 6-14.

[58] Kalan, L., Wright, G. D. (2011). Antibiotic adjuvants: Multicomponent anti-infective strategies. Expert Rev Mol Med. $13:$ e5.

[59] Natarajan, D., Srinivasan, R., Shivakumar, M. S. (2014). Phyllanthus wightianusMull. Arg.: A Potential Source for Natural Antimicrobial Agents. Biomed Res Int. 2014: 1-9.

[60] Rao, K., Bhuvaneswari, Ch., Lakshmi, M. N., Giri, A. (2009). Antibacterial Activity of Alpinia galangal (L) Willd Crude Extracts. Appl.Biochem.Biotechnol. 162: 871-884.

[61] Rao, P. M. J., Giri, A. (2010). Antimicrobial activity of the extracts of Salacia oblonga wall. Rec. Res. Sci. Tech. 2(10): 01-04.

[62] Lyumugabe, F., Jeanne, P. U., Claude, B., Emmanuel, B. S. (2017). Antimicrobial Activity and Phytochemicals Analysis of Vernonia aemulans, Vernonia amygdalina, Lantana camara and Markhamia lutea Leaves as Natural Beer Preservatives. Am. J. Food Technol. 12(1): 35-42.

[63] Kavit, M., Patel, B. N., Jain, B. K. (2013). Phytochemical analysis of leaf extracts of Phyllanthus fraternus. Res J Recent Sci. 2(ISC-2012): 12-15. https://www.researchgate.net/publication/321005031_Phytochemical_analysis_of_leaf_extract_of_Phyllanthus_fraternus.

[64] Jakobsen, T. H., Maria, V. G., Richard, K. P., Meenakshi, S. S., Louise, D. C., Morten, A. M. E. S., Thomas, B. R., Karlheinz, F., Friedrich, U., Peter, O. J., Claus, M., Kristian, F. N., Leo Eberl, Thomas, O. L., David, T., Niels, H., Thomas, B., Michael, G. (2012). Ajoene, a sulfur-rich molecule from garlic, inhibits genes controlled by quorum sensing. Antimicrob. Agents Chemother. 56: 2314-2325.

[65] Borges, A., Serra, S., Cristina Abreu, A., Saavedra, M. J., Salgado, A., Simoes, M. (2014). Evaluation of the effects of selected phytochemicals on quorum sensing inhibition and in vitro cytotoxicity. Biofouling. 30, 183-195.

[66] Mozirandi, W., Tagwireyi, D., Mukanganyama, S. (2019). Evaluation of antimicrobial activity of chondrillasterol isolated from Vernonia adoensis (Asteraceae). BMC Complementary and Alternative Medicine. 19: 249.

[67] Mladenka, P., Macakova, K., Filipsky, T., Zatloukalova, L., Jahodar, L., Bovicelli, P., Silvestri, I.P., Hrdina, R., Saso, L. (2011). In vitro analysis of iron chelating activity of flavonoids. J. Inorg. Biochem. 105: 693-701.

[68] Hatcher, H. C., Singh, R. N., Torti, F. M., Torti, S. V. (2009). Synthetic and natural iron chelators: Therapeutic potential and clinical use. Future Med Chem. 1: 1643-1670.

[69] Patel. (2005). Biofilms and antimicrobial resistance.Clin. Orthop. Relat. Res. 437: 41-47.

[70] Kris-Etherton, P. M., Hecker, K. D., Bonanome, A., Coval, S. M., Binkoski, A. E., Hilpert, K. F., Griel, A. E., Etherton, T. D., 
(2002). Bioactive compounds in foods: their role in the prevention of cardiovascular disease and cancer. Am. J. Med. 113: 715-885.

[71] Manson. (2003). Cancer prevention — the potential for diet to modulate molecular signalling. Trends Mol Med. 9: 11-18.

[72] Surh. (2003). Cancer chemoprevention with dietary phytochemicals. Nat. Rev. Cancer. 3(10): 768-780.

[73] Puupponen-Pimia, R., Nohynek, L., Alakomi, H., Oksman-Caldentey, K. (2008). The action of berry phenolics against human intestinal pathogens. Biofactors. 23(4): 243-251.

[74] Andreadi, C. K., Howells, L. M., Atherfold, P. A., Manson, M. M. (2006). Involvement of Nrf2, p38, B-Raf, and nuclear factor-kappa B, but not phosphatidylinositol 3-kinase, in induction of hemeoxygenase-1 by dietary polyphenols. MOL PHARMACOL. 69: 1033-1040.

[75] Sillankorv, S., Oliveira, R., Vieira, M. J., Sutherland, I., Azeredo, J. (2004). Bacteriophage phi S1 infection of Pseudomonas fluorescens planktonic cells versus biofilms. J Biofouling. 20(3): 133-138.

[76] Upadhyay, A., Upadhyaya, I., Kollanoor-Johny, A., Venkitanarayanan, K. (2014). Combating pathogenic microorganisms using plant-derived antimicrobials: a Mini review of the mechanistic basis. Biomed Res Int. 2014; 2: 761-41.

[77] Hawser, S. P., Douglas, L. J. (1994). Biofilm formation by Candida species on the surface of catheter materials in vitro. Infect Immun. 62: 915-21.

[78] Famuyide, I. M., Aro, A. O., Fasina, F. O., Eloff, J. N., McGaw, L. J. (2019). Antibacterial activity and mode of action of acetone crude leaf extracts of underinvestigated Syzygium and Eugenia (Myrtaceae) species on multidrug resistant porcine diarrhoeagenic Escherichia coli. BMC Vet Res. 15(1): 162. doi: 10.1186/s12917-019-1914-9. PMID: 31118023. PMCID:PMC6532232.

[79] Rafsanjany, N., Lechtenberg, M., Petereit, F., Hensel, A. (2013). Antiadhesion as a functional concept for protection against uropathogenic Escherichia coli: in vitro studies with traditionally used plants with antiadhesive activity against uropathognic Escherichia coli. J Ethnopharmacol. 145(2): 591-7.

[80] Trease, G., Evans, W. (1972). Pharmacognosy, Aberdeen, Great Britain: Univ. Press.

[81] Sabbineni. (2016). Phenol—An effective antibacterial agent. J. Med. org. Chem. 3(2): 182-191.

[82] Zhang, Y., Lewis, K. (1997). Fabatins: new antimicrobial plant peptides. FEMS Microbiol Lett. 149: 59-64.

[83] Suarez, M., Haenni, M., Canarelli, S., Fisch, F., Chodanowski, P., Servis, C., Michielin, O., Freitag, R., Moreillon, P., Mermod, N. (2005). Structure-Function Characterization and Optimization of a Plant-Derived Antibacterial Peptide. Antimicrob Agents Chemother. 49(9): 3847-3857.

[84] Abukakar, M. G., Ukwuani, A. N., Seshu, R. A. (2008). Phytochemical screening and antibacterial activity of Tamarindusindica pulp extract. Asian j. Biochem. 3: 134-138. DOI: 10.3923/ajb.2008.134.138. URL: https://scialert.net/abstract/? doi=ajb.2008.134.138.

[85] Agbafor, K. N., Akubugwo, E. I., Ogbashi, M. E., Ajah, P. M., Ukwandu, C. C. (2011). Chemical and antimicrobial properties of leaf extracts of Zapotecaportoricensis. Res. J. med. Plant. 5: 605-612. DOI: 10.3923/rjmp.2011.605.612. URL: https://scialert.net/abstract/?doi=rjmp.2011.605.612.

[86] Compean, K. L., Ynalvez, R. A. (2014). Antimicrobial activity of plant secondary metabolites: A Review. Res. J. med. Plant. 8(5): 204-213. DOI:10.3923/rjmp.2014.204.213. URL:https://scialert.net/abstract/?doi=rjmp.2014.204.213.

[87] Wink., Roberts. (1998). Alkaloids: Biochemistry, Ecology, and Medicinal Applications, chapter 12, Modes of action of alkaloids, Plenum Press, NewYork.

[88] Cushnie, T. P. T., Cushnie, B., Lamb, A. J. (2014). Alkaloids: An overview of their antibacterial, antibiotic-enhancing and antivirulence activities. Int. J. Antimicrob. Agents. 44: 377-86.

[89] Mariita, R. M., Ogol, C. K. P. O., Oguge, N. O., Okemo, P. O. (2011). Methanol extract of three medicinal plants from samburu in northern Kenya show significant antimycobacterial, antibacterial and antifungal properties. Res. J. med. Plant. 5: 54: 64.

[90] Sravanthi, P. S. S., Padmavathi, T. V. S., Giri, A. (2015). Anti-microbial activity of Phyllanthus amarus plant extracts using polar and non-polar solvents against gram positive and gram negative bacteria. Int J Curr Res. 7(12): 24687-24692.

[91] Sibi, G. P. Chatly., Adhikari, S., Ravikumar, K. R. (2012). Phytoconstituents and their influence on antimicrobial properties of Morinda citrifolia L. Res. J. med. Plant. 6: 441: 448.

[92] Sravanthi, P. S. S., Padmavathi, T. V. S., Giri, A. (2016). Metabolic fingerprinting of root, stem and leaf extracts of Phyllanthus amarus. J. Phytol. 8: 17-21.

[93] Thormar. (2011). Lipids and Essential Oils as Antimicrobial Agents; John Wiley \& Sons; Chichester. ISBN: 978-0-470-74178-8.

[94] Hamid, A. A., Fakai, I. M., Sani, I., Argungu, A. U., Bello, F. (2014). Preliminary phytochemical and antibacterial activity of ethanolic and aqueous stem bark extracts of Psidium guajava. Am. J. Drug Discov. Dev. 4: 85-89. https://scialert.net/fulltextmobile/?doi=ajdd.2014.85.89. DOI: 10.3923/ajdd.2014.85.89. URL: https://scialert.net/abstract/? doi=ajdd.2014.85.89. 
[95] Prasad, M. A., Zolnik, C. P., Molina, J. (2019). Leveraging phytochemicals: the plant Phylogeny predicts sources of novel Antibacterial compounds.Future Sci. OA 5(7), FSO407.

[96] Rao, A., Zhang, Y., Muend, S., Rao, R. (2010). Mechanism of antifungal activity of terpenoid phenols resembles calcium stress andinhibition of the TOR pathway. Antimicrob. Agents Chemother. 54:5062-5069.

[97] Arfa, B. A., Combes, S., Preziosi-Belloy, L., Gontard, N., Chalier, P. (2006). Antimicrobial activity of carvacrol related to its chemicalstructure. Lett. Appl. Microbiol. 43: 149-154.

[98] Pereira de Oliveira, F., Mendes, J. M., de Oliveira Lima, E. (2013). Investigation on mechanism of antifungal activity of eugenol against Trichophyton rubrum. Med. Mycol. 51: 507-513.

[99] Darvishi, E., Omidi, M., Bushehri, A. A., Golshani, A., Smith, M. L. (2013). The antifungal eugenol perturbs dual aromatic and branched-chainamino acid permeases in the cytoplasmic membrane of yeast. PLoS One. 8(10): e76028. doi: 10.1371/journal.pone.0076028.

[100] Khan, M. S., Ahmad, I. (2012). Antibiofilm activity of certain phytocompounds and their synergy with fluconazole against Candida albicans biofilms. J. Antimicrob. Chemother. 67: 618-621.

[101] Papageorgious, V. P., Assimopoulou, A. N., Ballis, A. C. (2008). Alkannins and Shikonins: A new class of wound healing agents. Curr Med Chem. 15: 3248-3267.

[102] Oboh. (2010). Antioxidant and antimicrobial properties of ethanolic extract of Ocimum gratissimum leaves. J Pharmacol Toxicol Methods. 5: 396-402.

[103] Meena, S. K., Premkumar, J., Chu Sing Lim., Thean Hock Tang., Kishore, R. S. (2010). Activity and interactions of antibiotic and phytochemical combinations against P. aeruginosainvitro. Int J Biol Sci. 6(6): 556-568.

[104] Paiva, P. M. G., Gomes, F. S., Napoleao, T. H., Sa, R. A., Correia, M. T. S., Coelho, L. C. B. B. (2010). Antimicrobial activityof secondary metabolites and lectins from plants, Current Research, Technology and Education topics in Applied Microbiology and Microbial Biotechnology. A.Mendez-vilas (Ed.), pp. 396-406.

[105] Sharon, N., Lis, H. (2001). The structural basis for carbohydrate recognition by lectins. Springer 2: 1-16.

[106] Hamed, El-SE., Ibrahim, El-AMM., Mounir, S. M. (2017). Antimicrobial Activities of Lectins Extracted from Some Cultivars of Phaseolus vulgaris seeds. J Microb Biochem Technol. 9(3): 109-116. doi: 10.4172/1948-5948.1000352. https://www.longdom.org/open-access/Antimicrobial-Activities-of-Lectins-Extracted-from-Some-Cultivars-of-Phaseolus-vulga ris-Seeds.pdf.

[107] Ratanapo, S., Ngamjunyaporn, W., Chulavatnatol, M. (2001). Interaction of a mulberry leaf lectin with a phytopathogenic bacterium, P. syringae pv mori. Plant Sci. 160(4): 739-744.

[108] Qadir, S., Wani, I. H., Rafiq, S., Ganie, S. A., Masood, A., Hamid, R. (2013). Evaluation of antimicrobial activity of a lectin isolated and purified from Indigofera heterantha. Adv Biosci Biotech. 4: 999-1006.

[109] Pompeu, D. G., Mattioli, M. A., Ribiro, A., Goncalves, D. B., Maglhaes, D., Marangoni, S., Silva, J. A., Granjeiro, P. A. (2015). Purification, partial characterization and antimicrobial activity of lectin from Chenopodium quinoa seeds. Food Sci Technol. Campinas, 35(4): 696-703, Out.-Dez. 2015,http://dx.doi.org/10.1590/1678-457X.6823.

[110] Berger, F. M., Hubbard, C. V., Ludwig, B. J. (1953). Antimicrobial action of glycerol ethers and related compounds. Journal of Appl Microbiol. 1(3): 146-149. PMCID: PMC1056886. PMID: 13041188.

[111] Baluja, S., Chanda, S., Nandha, K. (2015). Antimicrobial activity of some pyrimidine derivatives in DMF and DMSO. International Letters of Chemistry, Physics and Astronomy. 56: 131-141. https:// doi:10.18052/www.scipress.com/ILCPA.56.131. ISSN: 2299-3843. SciPress Ltd, Switzerland. Online: 2015-07-21.

[112] Porosa, L., Amanda, M., Gideon, W., Daniel, F. (2013). UV cured benzophenone terminated quaternary ammonium antimicrobials for surfaces, Nano safe coatings incorporated (A Florida corporation). Publication number: WO2014089680 A1, Application number: PCT/CA2013/001026.

[113] Chang-Liang He, Ben-Dong Fu, Hai-qing Shen, Xiao-lin Jiang, Xu-Bin Wei. (2011). Fumaric acid, an antibacterial component of Aloe vera L. Afr. J. Biotechnol. 10(15): 2973-2977. Available online at http://www.academicjournals.org/AJB. DOI: 10.5897/AJB10.1497 ISSN 1684-5315 @ 2011 Academic Journals.

[114] Florestano, H. J., Bahler, M. E. (2006). Antibacterial activity of a series of diphenylmethanes. J Am Pharm Assoc. 42(9): 576-578. https://www.ncbi.nlm.nih.gov/pubmed/13084475\#. PMID:13084475.DOI:10.1002/jps.3030420916.

[115] Abdullah, A. S. H., Mirghani, M. E. S., Jamal, P. (2011). Antibacterial activity of Malaysian mango kernel. Afr. J. Biotechnol. 10(81): 18739-18748. Available online at http://www.academicjournals.org/AJB. DOI: 10.5897/AJB11.2746 ISSN 1684-5315 (C)2011 Academic Journals.

[116] Barbieri, R., Coppo, E., Marcheseb, A., Daglia, M., Sobarzo-Sánchez, E., Nabavi, S. F., Nabavi, S. M. (2017). Phytochemicals for human disease: An update on plant-derivedcompounds antibacterial activity. Microbiological Research. 196(2017): 44-68.

[117] Lewis. (2013). Platforms for antibiotic discovery. Nat Rev Drug Discov. 12(5): 371-87.

[118] Lewis, K., Ausubel, F. M. (2006). Prospects for plant-derived antibacterials.Nat Biotechnol. di 24(12): 1504-7.

[119] Sharma, M., Manoharlal, R., Puri, N., Prasad, R. (2010). Antifungal curcumin induces reactive oxygen species and triggers an 
early apoptosis but prevents hyphae development by targeting the global repressor TUP1 inCandida albicans. Biosci Rep. 30: 391-404.

[120] Huyghebaert, G., Ducatelle, R., Van Immerseel, F. (2011). An update on alternatives to antimicrobial growth promoters for broilers. VET J. 187(2): 182-188.

[121] Dixon. (2001). Natural products and plant disease resistance. Nature. 411(6839): 843-7.

[122] Prakash. (2017). Applicability, Feasibility and efficacy of phytotherapy in aquatic animal health management. Am. J Plant Sci. 8: 257-287.

[123] Radulovic, N. S., Blagojevic, P. D., Stojanovic-Radic, Z. Z., Stojanovic, N. M. (2013). Antimicrobial plant metabolites: structural diversity and mechanism of action. Curr. Med. Chem. 20(7): 932-52.

[124] Mendoza, L., Wilkens, M., Urzua, A. (1997). Antimicrobial study of the resinous exudates and of diterpenoids and flavonoids isolated from some Chilean Pseudognaphalium (Asteraceae). J Ethnopharmacol. 58(2): 85-88.

[125] Griffin, S. G., Wyllie, S. G., Markham, J. L., Leach, D. N. (1999). The role of structure and molecular properties of terpenoids in determining their antimicrobial activity. Flavour Frag J. 14(5): 322-332. https://doi.org/10.1002/(SICI)10991026(199909/10)14:5\%3C322::AID-FFJ837\%3E3.0.CO;2-4.

[126] Cox, S. D., Mann, C. M., Markham, J. L., Bell, H. C., Gustafson, J. E., Warmington, J. R., Wyllie, S. G. (2000). The mode of antimicrobial action of the essential oil of Melaleucaalternifolia (tea tree oil). J Appl Microbiol. 88(1):170-175.

[127] Carson, C. F., Mee, B. J., Riley, T. V. (2002). Mechanism of action of Melaleuca alternifolia (tea tree) oil on Staphylococcus aureus determined by time-kill, lysis, leakage, and salt tolerance assays and electron microscopy. Antimicrob. Agents Chemother. 46(6): 1914-1920. https://www.ncbi.nlm.nih.gov/pubmed/12019108\#. PMID: 12019108. PMCID: PMC127210. DOI:10.1128/aac.46.6.1914-1920.2002.

[128] Brehm-Stecher, B. F., Johnson, E. A. (2003). Sensitization of Staphylococcus aureus and Escherichia coli to Antibiotics by the Sesquiterpenoids Nerolidol, Farnesol, Bisabolol, and Apritone.Antimicrob. Agents Chemother. 47(10): 3357-3360.

[129] Trombetta, D., Castelli, F., Sarpietro, M. G., Venuti, V., Cristiani, M., Daniele, C., Saija, A., Mazzanti, G., Bisignano, G. (2005). Mechanisms of Antibacterial Action of Three Monoterpenes. Antimicrob. Agents Chemother. 49(6): $2474-2478$.

[130] Enwa, F. O., Omojate, C. G., Adonu, C. (2013). A Review on the phytochemical profile and the antibacterial susceptibility pattern of some clinical isolates to the ethanolic leaves extract of Moringa oleifera lam (moringaceae). Int. J. Adv. Res. 1 (5): 226-238. ISSN- 2320-5407. http://www.journalijar.com/uploads/2013-07-31_195938_409.pdf.

[131] Lee, W., Lee, D. G. (2014). An antifungal mechanism of curcumin lies in membrane-targeted action within Candida albicans. IUBMB Life. 66: 780-785.

[132] Sundram, V., Chauhan, S. C., Ebeling, M., Jaggi, M. (2012). Curcumin attenuates-catenin signaling in prostate cancer cells through activation of protein kinase D1. PLos One. 7: e35368.

[133] Lee, J., Lee, D. G. (2015). Novel antifungal mechanisms of resveratrol: apoptosis inducer in Candida alibicans. Curr Microbiol. 70: 383-389.

[134] Wijesundara, N. M., Rupasinghe, V. H. P. (2019). Bactericidal and Anti-Biofilm Activity of Ethanol Extracts Derived from Selected Medicinal Plants against Streptococcus pyogenes.Molecules. 2019, 24, 1165.

[135] Gonelimali, F. D., Lin, J., Miao, W., Xuan, J., Charles, F., Chen, M., Hatab, S. R. (2018). Antimicrobial Properties and Mechanism of Action of Some Plant Extracts Against Food Pathogens and Spoilage Microorganisms. Front. Microbiol. 9: 1639.

[136] Gomes, F., Martins, N., Ferreira, I. C. F. R., Henriques, M. (2019). Anti-biofilm activity of hydromethanolic plant extracts against Staphylococcus aureus isolates from bovine mastitis. Heliyon. 5(2019): e01728.

[137] Mithofer, A., Boland, W. (2012). Plant defense against herbivores: chemical aspects. Annu Rev Plant Biol. 63: 431-50.

[138] Dhamgaye, S., Devaux, F., Vandeputte, P., Khandelwal, N. K., Sanglard, D., Mukhopadhyay, G., Prasad R. (2014). Molecular mechanisms of action of herbal antifungal alkaloid berberine, in Candida albicans. PLos One. 9: e104554.

[139] Bhadra, K., Maiti Mand Kumar, G. S. (2008). Berberine-DNA complexation: New insights into the cooperative binding and energetic aspects. Biochim. Biophys. Acta. 1780: 1054-1061.

[140] Zhu, S. L., Yan, L., Zhang, Y. X., Jiang, Z. H., Gao, P. H., Qiu, Y., Wang, L., Zhao, M. Z., Ni, T. J., Cai, Z., Tian, S. J., Zang, C. X., Zhang, D. Z., Jiang, Y. Y. (2014). Berberine inhibits fluphenazine-induced up-regulation of CDR1 in Candida albicans. Biol. Pharm. Bull. 37:268-273.

[141] Moyo, B., Masika, P. J., Muchenje, V. (2012). Antimicrobial activities of Moringa oleifera lam extracts. Afr. J. Biotechnol. 11(11): 2797-2802.

[142] Yun, J., Lee, H., Ko, H. J., Woo, E.R., Lee, D. G. (2015). Fungicidal effect of isoquercitrin via inducing membrane disturbance. Biochim. Biophys. Acta. 1848: 695-701.

[143] Sitheeque, M. A., Panagoda, G. J., Yau, J., Amarakoon, A. M., Udagama, U. R., Samaranayake, L. P. (2009). Antifungal activity of black tea polyphenols (catechins and theaflavins) against Candida species. Chemotherapy. 55: 189-196.

[144] Choi, H., Lee, D. G. (2015). Lycopene induces apoptosis in Candida albicans through reactive oxygen species production and 
mitochondrial dysfunction. Biochimie. 115: 108-115.

[145] Sung, W. S, Lee, I. S., Lee, D. G. (2007). Damage to the cytoplasmic membrane and cell death caused by lycopene in Candida albicans. J MICROBIOL BIOTECHN. 17: 1797-1804.

[146] Ferreira, A. L., Yeum, K. J., Matsubara, L. S., Matsubara, B. B., Correa, C. R., Pereira, E. J., Russell, R. M., Krinsky, N. I., Tang, G. (2007). Doxorubicin as an antioxidant: maintenance of myocardial levels of lycopene under doxorubicin treatment. Free Radic Biol Med. 43: 740-751.

[147] Plaper, A., Golob, M., Hafner, I., Oblak, M., Solmajer, T., Jerala, R. (2003). Characterization of quercetin binding site on DNA gyrase.Biochem Biophys Res Commun. 306(2): 530-536.

[148] Mirzoeva, O. K., Grishanin, R. N., Calder, P. C. (1997). Antimicrobial action of propolis and some of its components: the effects on growth, membrane potential and motility of bacteria. Microbiol. Res. 152(3): 239-246.

[149] Jones, G. A., McAllister, T. A., Muir, A. D., Cheng, K. J. (1994). Effects of sainfoin (Onobrychis viciifolia scop.) condensed tannins on growth and proteolysis by four strains of ruminal bacteria. Appl. Environ. Microbiol. 60: 1374-1375.

[150] De Vita, D., Friggeri, L. D., Auria, F. D., Pandolfi, F., Piccoli, F., Panella, S., Palamara, A. T., Simonetti, G., Scipione, L., Di Santo, R., Costi, R., Tortorella, S. (2014). Activity of caffeic acid derivatives against Candida albicans biofilm. Bioorg Med Chem Lett. 24(6): 1502-5. doi: 10.1016/j.bmcl.2014.02.005.

[151] Enwa, F. O., Omojate, C. G., JewoAugustina, O., Eze Christopher, O. (2014). Mechanisms of Antimicrobial Actions of Phytochemicals against Enteric Pathogens-A Review. J Pharm Chem Biol Sci. 2(2): 77-85. ISSN: 2348-7658. https://www.researchgate.net/publication/271507390_Mechanisms_of_Antimicrobial_Actions_of_Phytochemicals_against_Ent eric_Pathogens_-_A_Review.

[152] Gul, M. Z., Bhakshu, L. M., Ahmad, F., Kondapi, A. K., Qureshi, I. A., Ghazi, I. A. (2011). Evaluation of Abelmoschus moschatus extracts for antioxidant, free radical scavenging, antimicrobial and antiproliferative activities using in vitro assays. BMC Complement Altern Med. 11:64. https://doi.org/10.1186/1472-6882-11-64.

[153] Kavitha, R., Uduman Mohideen, A. M. (2017). Identification of Bioactive Components and Its Biological Activities of Abelmoschas moschatus Flower Extrtact-A GC-MS Study. IOSR J. Appl. Chem. 10(11): 19-22.

[154] Wan-Ibrahim, W. S., Tuan Nadrah, N. T. I., Siti Farhanah, M., Norzila, I. (2018). GC-MS Analysis of Phytochemical Compounds in Aqueous Leaf Extract of Abrus Precatorius. Pertanika J. Trop. Agric. Sci. 41(1): 241-250.

[155] Abubakar, M. N., Majinda Runner, R. T. (2016). GC-MS Analysis and Preliminary Antimicrobial Activity of Albizia adianthifolia (Schumach) and Pterocarpus angolensis (DC). Medicines (Basel). 3(1): 3. doi: 10.3390/medicines3010003. PMCID: PMC5456228. PMID: 28930113.

[156] Batain, F., Crescencio, K., Alves, T., Souza, J. F., Amaral, V., Castro, J., Santos, C., Jozala, A., Lopes, L., and Chaud, M. (2020). Medicinal plant extract associated with bacterial cellulose membrane: Antibacterial activity and physicochemical properties. Arch Pharm Pharma Sci. 2020; 4: 013-020.

[157] Senhaji, S., Lamchouri, F., Toufik, H. (2020). Phytochemical Content, Antibacterial and Antioxidant Potential of Endemic Plant Anabasis aretioïdes Coss.\& Moq. (Chenopodiaceae) Hindawi BioMed Research International. Volume 2020, Article ID 6152932, 16 pages https://doi.org/10.1155/2020/6152932.

[158] Jegadeeswari, P., Nishanthini, A., Muthuasamya, S., Mohan, V. R. (2012). GC-MS analysis of bioactive components of Aristolochia krysagathra (Aristolochiaceae). J Curr Chem Pharm Sci. 2(4): 226-232. https://www.tsijournals.com/abstract/ gcms-analysis-of-bioactive-components-of-aristolochia-krysagathra-aristolochiaceae-11419.html. ISSN-2277-2871.

[159] Elezabeth, V. D., Arumugam, S. (2014). GC-MS Analysis of Ethanol Extract of Cyperus rotundus Leaves. Int. J. Curr. Biotechnol. 2(1): 19-23. ISSN: 2321-8371.

[160] Promprom, W., Wannachai, C. (2017). GC-MS Analysis and Antioxidant Activity of Bauhinia nakhonphanomensis Leaf Ethanolic Extract. Phcog J. 9(5): 663-667.

[161] Chiavari-Frederico, M. O., Barbosa, L. N., Carvalho dosSantos, I., Ratti da Silva, G., Fernandes de astro, A., Campos Bortolucci, W., Barboza, L. N., Almeida Campos, C. F., Jose Goncalves, E., Menetrier, J. V., Jacomassi, E., Gazim, Z. C., Wietzikoski, S. (2020). Antimicrobial activity of Asteraceae species against bacterial pathogens isolated from postmenopausal women. PLOS ONEhttps://doi.org/10.1371/journal.pone. 0227023: 1-14.

[162] Taechowisan, T., Suchanya, C., Waya, S. P. (2017). Antibacterial, antioxidant and anticancer activities of biphenyls from Streptomyces sp. BO-07: an endophyte in Boesenbergia rotunda (L.) Mansf A. Food Agric Immunol. 28(6): 1330-1346.

[163] Franelyne, P. C., Agnes, L. C., Mary Jho-Anne, T. C. (2016). GC-MS analyses of bioactive compounds present in different extracts of an endemic plant Broussonetia luzonica (Blanco) (Moraceae) leaves. Asian Pac J Trop Biomed. 6(11): 957-961. https://doi.org/10.1016/j.apjtb.2016.08.015.

[164] Revathi, P., Jeya seelan senthinath, T., Thirumalaikolundhu subramaian, P. (2015). Preliminary Phytochemical Screening and GC-MS Analysis of Ethanolic Extract of Mangrove Plant-Bruguiera Cylindrica (Rhizho) L. International Journal of Pharmacognosy and Phytochemical Research. 6(4): 729-740.

[165] Prabhakaran, J., Kavitha, D. (2012). Ethnomedicinal importance of Mangrove species of Pitchavaram. Int J. Res Pharma Biomed Sci. 3(2): 611-614. 
[166] Ravikumar, S., Gnanadesigan, M., Suganthi, P., Ramalakshmi, A. (2010). Antibacterial potential of chosen mangrove plants against isolated urinary tract infectious bacterial pathogens. Int. J. Med. Med. Sci. 2(3): 94-99.

[167] Kumar. (2014). Plant profile, phytochemistry and pharmacology of Avartani (Helicteres isora Linn.): A review. Asian Pac J Trop Biomed. 4(1): S22-S26.

[168] Mythili, K., Reddy, C. U., Chamundeeswari, D., Manna, P. K. (2013). GC-MS analysis of phytocomponents andin-vitro inhibitory effects of Calanthe triplicate. J. Nat. Prod. 6(2013): 141-146.

[169] Manorenjitha, M. S., Norita, A. K., Norhisham, S., Asmawi, M. Z. (2013). GC-MS analyses of bioactive components of Ficus religiosa (LINN.) stem. Int J Pharm Bio Sci. 4(2): 99-103.

[170] Azab Abdullatif. (2017). CAROB (Ceratonia siliqua): Health, medicine and chemistry. Eur. Chem. Bull. 6(10): 456-469. DOI: 10.17628/ecb.2017.6.456-469.

[171] Elansary, H. O., Agnieszka Szopa., Kubica, P. B., Halina Ekiert., Hayssam, M. A., Mohamed, S. E., Abdel-Salam, E. M., Mohamed El-Esawi., Diaa O El-Ansary. (2018). Bioactivities of Traditional Medicinal Plants in Alexandria. J Evid Based Complementary Altern Med. Article ID 1463579. https://doi.org/10.1155/2018/1463579.

[172] Perumal, R., Sathya, A., Brindha, Pemiah. (2018). GC-MS Evidence Based Herbocure from Indian System of Medicine for Stomach Disorders in Vets. Asian J Anim Vet Adv. 13(1): 73-84.

[173] Venkataraman, B., Samuel, L. A., Pardha Saradhi, M., Narashimha Rao, B., Naga Vamsi Krishna., Sudhakar, M., Radhakrishnan, T. M. (2012). Antibacterial, antioxidant activity and GC-MS analysis of Eupatoriumodoratum. Asian J Pharm Clin Res. 5(2): 99-106.

[174] Sugumar, N., Karthikeyan, S. (2015). Preliminary Phytochemical Screening GC-MS and FTIR Profiling of Methanolic Extract of Leaves on Eupatorium triplinerve Vahl. Int. J. Multidiscip. Res. Dev. 2(8): 335-340.

[175] Rajeswari, G., Murugan, M., Mohan, V. R. (2013). GC-MS analysis of bioactive components of Hugonia mystax L. barks (Linaceae). J Pharm Biomed Sci. 29(29): 818-824.

[176] Zeb, A., Farhat, U., Muhammad, A., Sajjad, A., Abdul, S. (2017). Demonstration of biological activities of extracts from Isodon rugosus Wall. Ex Benth: Separation and identification of bioactive phytoconstituents by GC-MS analysis in the ethyl acetate extract. BMC COMPLEM ALTERN M. 17: 284.

[177] Lee, S. W., Wendy, W., Julius, Y. F. S., Desy, F. S. (2011). Characterization of antimicrobial, antioxidant, anticancer property and chemical composition of Michelia champaca seed and flower extracts. Stamford j. pharm. sci. 4(1): 19-24.

[178] Saha, H., Apoorva, S., Siddharth, S., Devi Rajeswari, V. (2015). Comparative Evaluation of Antimicrobial and Anti-Inflammatory Activities of Ocimum sanctum, Phyllanthus niruri and Cadaba fruticosa: An in vitro Approach with Emphasis on Detection of their Bioactive Compounds Using GC-MS. Int. J. Biol. Chem. 9(5): 235-248.

[179] Getasetegn, M., Tefera, Y. (2016). Biological Activities and Valuable Compounds from Five Medicinal Plants. Nat Prod Chem Res. 4(4): 220. DOI: 10.4172/2329-6836.1000220. ISSN: 2329-6836.

[180] Swamy, M. K., Greetha, A., Ravinder, K., Ali, G., Mazina, M. Y., Uma Rani, S. (2017). GC-MS Based Metabolite Profiling, Antioxidant and Antimicrobial Properties of Different Solvent Extracts of Malaysian Plectranthus amboinicus Leaves. J Evid Based Complementary Altern Med.Article ID 1517683, 10 pages.

[181] Elnakady, Y. A., Ahmed, I. R., Raimo Franke., Nael Abutaha., Hossam Ebaid., Mohannad Baabbad,, Mohamed, O. M. O., Ahmad A Al Ghamdi. (2017). Characteristics, chemical compositions and biological activities of propolis from Al-Bahah, Saudi Arabia. Sci. Rep. 7:41453. doi: 10.1038/srep41453.

[182] Mbosso, E. J., Ngouela, S., Nguedia, J. C., Beng, V. P., Rohmer, M., Tsamo, E. (2010). Invitro antimicrobial activity of extracts and compounds of some selected medicinal plants from Cameroon. J Ethnopharmacol. 128(2): 476-481.

[183] Anjaneyulu, M., Giri, A. (2019). Investigation of Mode of Action of Anti-Bacterial Activity of Salacia oblonga extract against drug resistant pathogen. Brazilian Archives of Biology and Technology. 62: e19180051, http://dx.doi.org/10.1590/1678-4324-2019180051. ISSN 1678-4324 Online Edition.

[184] Asong, J. A., Amoo, S. O., McGaw, L. J., Nkadimeng, S. M., Aremu, A. O., Otang-Mbeng, W. (2019). Antimicrobial Activity, Antioxidant Potential, cytotoxicity and phytochemical profiling of four plants locally used against Skin Diseases. Plants, 8, 350; doi: 10.3390/plants8090350.

[185] Adnan, M., Ali, S., Sheikh, K., Amber, R. (2019). Review on antibacterial activity of Himalayan medicinal plants traditionally used to treat pneumonia and Tuberculosis. J Pharm and Pharmacol, 71: 1599-1625.

[186] Okeke., I. C., Ezeabara, C. A. (2018). Phytochemical screening and in vitro antimicrobial activity of various parts of Cleome ciliata Schum. \& Thonn. Bioscience Horizons. 11.10.1093/biohorizons/hzy018.

[187] Yadav, S. (2019). Assessment of antimicrobial activity of selected plant extracts for application on textiles. Int. J. of Chem. Stud. 7(1): 33-36.

[188] Safari, M., Ahmady-Asbchin, S. (2019). Evaluation of antioxidant and antibacterial activities of methanolic extractof medlar (Mespilus germanica L.) leaves. Biotechnology \& biotechnological equipment. 33(1): 372-378.

[189] Sood, H., Kumar, Y., Gupta, V. K., Arora, D. S. (2019). Scientific validation of the antimicrobial and antiproliferative potential 
of Berberis aristata DC root bark, its phytoconstituents and their biosafety. AMB Expr. (2019)9: 143. https://doi.org/10.1186/s13568-019-0868-4.

[190] Agarwal, S., Ramamurthy, P. H., Fernandes, B., Rath, A., Sidhu, P. (2019). Assessment of antimicrobial activity of different concentrations of Tinospora cordifolia against Streptococcus mutans: An in vitro study. Dent Res J. 16(1): 24-28. Available from: http://www.drjjournal.net/text.asp?2019/16/1/24/249556.

[191] Askarinia, M., Ganji, A., Jadidi-Niaragh, F., Hasanzadeh, S., Mohammadi, B., Ghalamfarsa, F., Ghalamfarsa, G., Mahmoudi, H. (2019). A review on medicinal plant extracts and their active ingredients against methicillin-resistant and methicillin-sensitive Staphylococcus aureus. J Herbmed Pharmacol. 2019; 8(3): 173-184. doi: 10.15171/jhp.2019.27.

[192] Atef, N. M., Shanab, S. M., Negm, S. I., Abbas, Y. A. (2019). Evaluation of antimicrobial activity of some plant extracts against antibiotic susceptible and resistant bacterial strains causing wound infection. Bull. Natl. Res. Cent. (2019) 43 : 144. https://doi.org/10.1186/s42269-019-0184-9.

[193] Durgawale, P. P., Patil, M. N., Joshi, S. A., Korabu, K. S., Datkhile, K. D. (2019). Studies on phytoconstituents, in vitro antioxidant, antibacterial, antiparasitic, antimicrobial, and anticancer potential of medicinal plant Lasiosiphon eriocephalus decne (Family: Thymelaeaceae). J Nat Sc Biol Med. 10:38-47. Available from: http://www.jnsbm.org/text.asp?2019/10/1/38/251501. 